\title{
Geç Dönem Osmanlı Kız Mekteplerinde Fennî Ev İdaresi Eğitimi: Müifredat ve Ders Kitapları
}

\section{Teaching Scientific Home Economics in Late Ottoman Girls' Schools: Curriculum and Textbooks}

\author{
Fatma TUNÇ YAŞAR ${ }^{1}$
}

'Sorumlu yazar/Corresponding author: Fatma Tunç Yaşar (Dr. Öğr. Üyesi), Yıldız Teknik Üniversitesi, Fen Edebiyat Fakültesi, Insan ve Toplum Bilimleri Bölümü, Esenler, Istanbul, Türkiye

E-posta: ftyasar@yildiz.edu.tr

ORCID: 0000-0002-8623-4822

Başvuru/Submitted: 21.03.2019 Revizyon Talebi/Revision Requested: 15.08.2019

Son Revizyon/Last Revision Received: 09.09.2019

Kabul/Accepted: 24.09.2019

Online Yayın/Published Online: 31.10.2019

Atıf/Citation: Tunc Yasar, Fatma. "Geç Dönem Osmanlı Kız Mekteplerinde Fennî Ev İdaresi Eğitimi: Müfredat ve Ders Kitapları." Türkiyat Mecmuasi-Journal of Turkology 29, 2 (2019): 591-620.

https://doi.org/10.26650/iuturkiyat.640768 öz

Bilimsel verilere ve modern standartlara dayalı ev idaresi düşüncesi on dokuzuncu yüzyılda gündeme gelmiş ve yüzyılın ortalarından itibaren ev idaresi bağımsız bir ders olarak kız okullarının müfredat programlarında yer almaya başlamıştır. Ev idaresi bilimsel bir alan olarak evin düzeni, fiziksel koşulları, temizlik, evde sağlık, ısınma, giyim, çocukların bakımı ve terbiyesi, yemek, sofra düzeni ve âdâb-ı muâşeret gibi ev ile ilgili pek çok konuda bilimsel ve pedagojik standartlar belirlemekte ve bu şekilde evde profesyonelliği ve verimliliği artırmayı hedeflemektedir. Modernleşme öncesi Osmanlı dünyasında, ahlakın konusu olan ve ahlak kitaplarının bir bölümünü oluşturan ev idaresi, on dokuzuncu yüzyılın ikinci yarısından itibaren kitaplar ve süreli yayınlarda müstakil bir alan olarak ele alınmakta ve kız mekteplerinde ders olarak okutulmaktadır. Standart, disiplin, düzen, rasyonellik, pragmatizm ve hijyen bu yeni ev idaresinin ana prensiplerini oluşturmaktadır. Bu makale, devletin eğitim politikası olarak ev idaresinin geç dönem Osmanlı kız mekteplerinde fenne dayalı bir ders olarak okutulmasını ele almakta ve bu bağlamda ders kitaplarını, talimatnameleri, nizamnameleri ve süreli yayınları incelemektedir. Makale, kız mekteplerinin müfredat programında ev idaresi derslerinin yerini ve ağırlığını irdelemekte ve ilgili müfredat programlarının ve ders kitaplarının gündemi ile muhtevasını, Osmanlı modernleşmesi ve kadınların eğitimi meselesi çerçevesinde tartışmaktadır.

Anahtar kelimeler: Ev idaresi, Müfredat, Ders Kitabı, Eğitim, Osmanlı

\section{ABSTRACT}

The idea of home economics based on scientific knowledge and modern standards emerged in the nineteenth century, and from the middle of the century onwards, home economics began to be part of the curriculum of girls' schools as an independent course. As a scientific field of study, home economics defines scientific and pedagogical standards in many subjects related to home life such as the organization and physical condition of the house, house-cleaning, health issues, heating, dressing, raising of children, eating, table manners, and etiquette. In this way, it aims to increase professionalism and productivity at home. In the pre-modern Ottoman world, home economics, which was considered as a subject of ethics and covered as a chapter in the ethics books, began to be taken as an independent field in books and periodicals after the second half of the nineteenth century and was 
also taught as a course in girls' schools. Standards, discipline, order, rationality, pragmatism, and hygiene emerged as the major principles of this new version of home economics. This article focuses on the teaching of home economics as a science-based course in late Ottoman girls' schools as the educational policy of the state and examines the related textbooks, guidelines, regulations, and periodicals in this context. The article scrutinizes the place and weight of home economics courses in the curriculum of girls' schools and discusses the agenda and content of related curriculums and home economics textbooks in the context of the Ottoman modernization process and women's education.

Keywords: Home economics, Curriculum, Textbook, Education, Ottoman

\section{EXTENDED ABSTRACT}

Home economics appeared as an independent field of research in the nineteenth century and began to be included in the curriculum of girls' schools in many countries through the second half of the century. As a scientific field, home economics defines systematic, modern and pedagogical standards for housework with a particular focus on household chores being part of the daily routine and aims to increase productivity and professionalism at home. Standardization, discipline, order, rationality, pragmatism, and hygiene appeared as the main principles of home economics. These principles defined the reform programs of many states, which were initiating a modernization process in the realms of political, economic and sociocultural areas in the nineteenth century. These principles are also among the main criteria of Norbert Elias's definition of the civilizing process, which he defined by focusing on the change and transformation of the standards of correct and proper behavior in Europe from the thirteenth to the nineteenth centuries. Therefore, the rational and scientific approach to house related issues and the introduction of home economics as a course to the curriculum of girls' schools appear closely related to the modernization and civilizing attempts of the states.

In the pre-modern Ottoman world, home administration (ilm-i tedbir-i menzil), which was considered as a subject of ethics and included as a chapter in ethics books, began to be taken as an independent field as home economics (idâre-i beytiye) in books and periodicals after the second half of the nineteenth century as well as being taught as a course in girls' schools through the last quarter of the century. Ottoman authors examined the decoration and physical conditions of the house, house-cleaning, health issues, heating, dressing, raising of children, eating and food, table manners, etiquette and all kinds of issues that may be related to the house under the title of home economics. The target of writing on home economics was the disciplining and rationalization of the Ottoman house life with definite standards. This literature criticized the traditional Ottoman house life as being scattered, irregular, and haphazard and proposed a new model of house management based on scientific, rational and pedagogical data, dominated by discipline, order, and hygiene.

The opening of new schools for girls at different levels from primary schools to teachers' schools was an important development for the participation of Ottoman women in the formal education process. Furthermore, the discussions to define the object and content of girls' curriculum reveals that Ottoman authorities considered the education of women within 
the perspective of the traditional role and status of Ottoman women as housewife, wife, and mothers despite Ottoman women beginning to benefit from the possibilities of formal education and public life. It seems that the number and the weight of courses related to home economics increased in the curriculum of girls' schools of the time and attempts were made to fill the girls' curriculum with those sciences regarded as necessary and useful to femininity, housewifery, and motherhood. The language used in the Ottoman textbooks of home economics shows that the traditional female discourse continued in many aspects. It seems that this literature on home economics aims to reorganize the living space of the family, which is the nucleus of the society according to the scientific, rational, technological and pedagogical standards and approaches of the age.

With the introduction of the home economics courses to the curriculum of Ottoman girls' schools in different levels and the definition of women's status as home managers, domestic life became a public issue and also a political matter on which state and public authorities developed policies. Because these books are textbooks for girls' schools and each textbook is published with the permission of the Ministry of Education, it can be said that the woman's discourse emerging from these books not only represents the idea of authors but also the policy of Ottoman political authorities. However, the introduction of home economics to the curriculum of girls' schools both in the Ottoman and western world was not a result of an agenda to question or improve women status, rather it seems like a consequence of a process initiated by the state authorities to modernize all segments of life. In this context, the involvement of the course in the curriculums seems primarily related to the modernization and civilization process in almost every realm of Ottoman life from the second half of the nineteenth century, and the Ottoman house which was an area that needed to be reorganized in line with modern standards to serve and contribute to this change and transformation process. 


\section{Giriş}

Bilimsel verilere ve modern standartlara dayalı ev idaresi düşüncesi on dokuzuncu yüzyılda gündeme gelmiş ve yüzyılın ortalarından itibaren dünyanın birçok ülkesinde ev idaresi bir ders olarak kız okullarının müfredat programlarında yer almaya başlamıştır. Ev idaresi bilimsel bir alan olarak ev hayatına ve daha özelde gündelik ev rutini içerisinde kabul edilen ev işlerine bilimsel ve pedagojik standartlar belirlemekte ve bu şekilde evde üretkenliği ve verimliliği artırmayı hedeflemektedir. ${ }^{1}$ Standart, disiplin, düzen, rasyonellik, pragmatizm ve hijyen, bu yeni ev idaresinin ana prensiplerini oluşturmaktadır. Aslında bu prensipler, on dokuzuncu yüzyılda siyasi, iktisâdi ve sosyokültürel pek çok alanda modernleşme sürecine giren devletlerin reform programlarının da ana hatlarını belirlemiş ve Norbert Elias'ın on üçüncü yüzyıldan on dokuzuncu yüzyıla değin Avrupa'da doğru davranış biçimlerinin standartlarının değişim ve dönüşümü üzerinden tanımladığı medenileşme sürecinin de başlıca kriterleri arasında yer almıştır. ${ }^{2}$ Dolayısıyla on dokuzuncu yüzyıl itibarıyla ev idaresinin rasyonel ve bilimsel temelli bir perspektiften yeniden ele alınması ve kız okullarının ders programlarına dâhil edilmesi, modernleşme ve medenileşme gibi kavramlarla ifade edilen değişim ve dönüşüm süreçleri ile bağlantılıdır. ${ }^{3}$

Osmanlı dünyasında ev idaresi, on dokuzuncu yüzyılın ikinci yarısından itibaren kitaplar ve süreli yayınlarda müstakil bir alan olarak ele alınmakta ve kız mekteplerinde ders olarak okutulmaktadır. Ev hayatının belirli standartlarda disipline edilmesi ve rasyonelleştirilmesi anlayışı çerçevesinde evin düzeni, fiziksel koşulları, hijyen, evde sağlık, ısınma, kıyafetlerin düzeni ve temizliği, çocukların bakımı ve terbiyesi, yemek, sofra düzeni, âdâb-1 muâşeret gibi ev ile ilgili olabilecek her türlü konu ev idaresi başlı̆̆ altında incelenmekte ve geleneksel Osmanlı ev idaresi birçok açıdan eleş̧irilmektedir. Ev idaresi, ilgili literatürde ilm-i tedbîr-i menzil, idâre-i beytiye, iktisâd-ı beytî gibi benzer çağrışımları olan fakat farklı bağlamlarda kullanılan kavramlarla ifade edilmektedir. Önemli bir kısmı ders kitabı olan bu literatürün on dokuzuncu yüzyılın ikinci yarısından itibaren çoğunlukla kız çocuklarının eğitimi bağlamında kadınlara hitaben kaleme alınmış olduğu görülmektedir. Kadınlara verilen ev idaresi eğitimi vasıtasıyla toplumun çekirdeği olan ailenin yaşam alanının çağın bilimsel, rasyonel,

1 Bir uzmanlık alanı olarak ev idaresi ve eğitimi, ilki 1899 yılında gerçekleşen Lake Placid Konferansları'nda çok yönlü olarak tartışılmış ve ev idaresinin ana hatları belirlenmiştir. On yıl kadar süren bu konferanslarda ev idaresi eğitiminin müfredat programlarındaki yeri ve içeriği, dersi verecek olan öğretmenlerin eğitimi, yükseköğretimde ev idaresi, araştırma alanları ve aile refahı gibi konular ele alınmış ve nihayet onuncu konferansta Amerikan Ev İdaresi Derneği'nin kurulmasıyla ev idaresi (home economics) alanın ismi olarak resmileşmiştir. Virginia M. Richards, "The Postmodern Perspective on Home Economics History”, Journal of Family and Consumer Sciences 92/1 (2000), 81.

2 Norbert Elias, The Civilizing Process: The History of Manners and State Formation and Civilization, çev. Edmund Jephcott (Oxford UK \& Cambridge USA: Blackwell, 1994), xii.

3 Cumhuriyet'in ilk yıllarında devam ettirilen modernleşme ve asrileşme politikalarının merkezinde ev yine önemli bir yere sahiptir. 1928 yılında açılan kız enstitüleri, Türk kızlarını ulusal değerlerle yetiştirmeyi ve onları ev işlerinde daha "verimli” hale getirmeyi amaçlamaktadır. Bkz. Yael Navaro-Yaşın, ““"Evde Taylorizm”: Türkiye Cumhuriyeti’nin İlk Yıllarında Evişinin Rasyonelleşmesi (1928-40)”, Toplum ve Bilim 84 (Bahar 2000), 52 . 
teknolojik ve pedagojik yaklaşımları çerçevesinde yeniden düzenlenmesi amaçlanmaktadır. Bu bağlamda, ev idaresi kadınlara yönelik eğitiminin önemli bir veçhesi olarak görülmekte, kız çocuklarının okul merkezli eğitim sürecinde ev idaresi öğrenmeleri beklenmektedir.

\section{Kadınların Eğitimi: Matbuat ve Tedrisat Alanında Yenilikler}

Osmanlı'da on dokuzuncu yüzyıl öncesinde kız çocuklarının eğitimi sıbyan mektepleri ve sonrasında kendi mahallelerinde bulunan ev mekteplerinde gerçekleşmektedir. Bu eğitimin dışında ailenin talebi doğrultusunda kız çocukları için ev ortamında eğitim söz konusu olabilmektedir. Bu sınırlı eğitim, kız çocuklarını eş, anne ve ev kadını olarak gelecekteki rollerine hazırlama amacı gütmektedir. 1900'lü yılların başında geleneksel Osmanlı hayatının adet ve merasimlerine dair yazan Abdülaziz Bey, Osmanlı'da kız çocuklarının okumayı ve dinî vazifelerini öğrendikten sonra daha küçük yaşlardan itibaren iyi bir ev reisesi olmak üzere yetiştirildiklerini ifade etmektedir. Abdülaziz Bey’in aktardıklarına göre sıbyan mekteplerinden sonra mahallelerindeki ev mekteplerine devam eden kızlardan yaşı büyük olanlar cuma gününe ilaveten pazartesi de okula gitmemekte, haftanın iki gününü evlerinde bez dokumak, çeyiz hazırlamak ve nakış işlemek gibi işlerle geçirerek ev reiseliğine hazırlanmaktadırlar. Kız çocuklarının ev idaresi öğrenme zorunluluğu onların devam ettikleri ev mekteplerinden belirli günlerde izinli sayılmalarını sağlamakta ve ev idaresi öğrenme süreci evde ve aile ortamında gerçekleşmektedir. ${ }^{4}$

Öte yandan kız çocukları için geleneksel eğitimin yetersizliği on dokuzuncu yüzyılın başlarından itibaren tartışılmaktadır. Bu dönemde, kadınların eğitimden yoksunlukları ile toplumun geri kalmışlığı arasında doğrudan ilişki kurulmuştur. Toplumun temeli olarak kabul edilen aile içerisinde kadının belirleyici rolü kabul edilmiş ve kadınların eğitilmesi ve bilinçlendirilmesi zorunluluğuna dikkat çekilmiştir. Yüzyılın ikinci yarısından itibaren kadınlara yönelik olarak hazırlanan kitaplar ve süreli yayınlar matbuat alanında yaşanan önemli gelişmelerdir. Genellikle “Kadınlı̆̆a dair nâfi şeylerden bahseder.” sloganıyla yayın yapan kadın dergileri, kadınının geleneksel ev kadınlığı rolünü daha iyi koşullarda ve standartlarda yerine getirebilmesi için Osmanlı kadınını eğitmeyi amaçlamaktadır. Özellikle II. Meşrutiyet öncesi kadın dergilerinde ev idaresi, ev temizliği ve düzeni, çocuk bakımı ve sağlığı, çocuk eğitimi ve terbiyesi, evlilik ve eşler arası ilişkiler konusunda çok sayıda makale yer almakta ve kadının eğitimli ve donanımlı bir ev hanımı, eş ve anne olmasının gerekliliği vurgulanmaktadır. ${ }^{5}$

1869 yılında Terakkî gazetesinin ilavesi olarak yayın hayatına başlayan ve kadınlara yönelik ilk süreli yayın olarak kabul edilen Terakkî-i Muhadderât Osmanlı kadınının geri kalmışlığını ve eğitimsizliğini gündeme taşımaktadır. Kadınları erkeklere nispetle aklen ve

4 Abdülaziz Bey, Osmanlı Âdet, Merasim ve Tabirleri, ed. Kazım Arısan, Duygu Arısan Günay (İstanbul: Tarih Vakfi Yurt Yayınları 1995), 102.

5 Fatma Tunç Yaşar, “İlk Kadın Dergilerinde 'Kadınlık': İffetli ve Mektepli”, Harf Harf Kadınlar, ed. Nazife Şişman (İstanbul: Klasik Yayınları, 2008), 100. 
bedenen daha zayıf kabul eden Terakkî-i Muhadderât yazarı Ali Raşid, kadınlara yönelik eğitimin çerçevesini kadınların ev merkezli rolleri bağlamında belirlemekte, kadınların eş ve anne olmalarının dışında en önemli vazifesinin ev idaresi olduğunu vurgulamaktadır. Ali Raşid'e göre “Kadın kısmı kendi cüsseleri icabından olarak ev işlerine bakmak, çocuk terbiye etmek ve kocalarının istirahatini istilzam edecek işleri görüvermek gibi daima küçük ve kolay işlere bakarlar. Ev kadını olmakla iftihar ederler." "Derginin tek yazarı olan Ali Raşid, evdeki iş bölümünün kadın ve erkeğin akli ve bedeni meziyetleri doğrultusunda, Şer'en tanımlanmış olan sorumluluk ve yetkiler çerçevesinde belirlenmesi gerektiğini iddia etmekte, zevç ve zevceyi ortaklık kurmuş kişilere benzetmektedir. ${ }^{7}$ Ona göre tarafların birbirlerine karşı sorumlulukları vardır ve taraflardan biri sorumluluklarını yerine getirmediğinde bu ortaklık sona ermektedir. Buna göre erkeğin görevi evin geçimini sağlamaktır, kadının görevi ise ev içindeki işler ile meşgul olmak ve kocasının zahmetle kazandığ 1 erzakı telef etmemektir. ${ }^{8}$

Osmanlı' da kız çocuklarının örgün eğitim sürecine dâhil olması ise eğitimin imparatorluk genelinde kitleselleşmesine yönelik girişimlerin bir sonucudur. Din, dil, rrk ve cinsiyet gözetmeksizin tüm unsurların devlet merkezli eğitim sürecine dâhil edilmesiyle birlikte kız çocuklarına mahsus mektepler açılmıştır. İlki 1858 yılında Sultanahmet’te açılan ve sonrasında İmparatorluk geneline yayılan kız rüşdiyeleri geleneksel eğitim sisteminde sıbyan mektebinden sonra okul hayatı sona eren kız çocuklarına eğitime devam etme imkânı sunmuştur. ${ }^{9}$ Kızlara mahsus sıbyan ve rüşdiye mekteplerinde ortaya çıkan kadın öğretmen ihtiyacı dolayısıyla 1869 tarihli Maârif-i Umûmiye Nizamnâmesi ile kız sıbyan ve rüşdiye mekteplerine öğretmen yetiştirmek amacıyla dârülmuallimâtın açılmasına karar verilmiş ve 1870 yılında Sultanahmet'te ilk dârülmuallimât açılmıştır. ${ }^{10}$ Yeni açılan mekteplere kız çocuklarını göndermeye teşvik etmek için kız çocuklarının eğitiminin zorunluluğu farklı mecralarda dile getirilmiştir. Sultanahmet'te açılan ilk kız rüşdiyesine çocuklarını göndermeye aileleri teşvik etmek üzere 24 Haziran 1862 tarihli Takvim-i Vekâyi nüshasında bir ilan yayımlanmıştır. İlanda ilim tahsilinin kadın ve erkeğe farz olduğu hatırlatılmakta, ağır geçim yükü omuzlarında olan zevçlerin refah ve asayişinin kadınların din ve dünyalarını bilmelerine, emre itaat etmelerine, yasaklardan uzak durmalarına, iffet ve kanaat sahibi olmalarına bağlı olduğu ifade edilmektedir. İlanda kız çocuklarının terbiye ve âdâba vakıf olarak yetiştirilmelerinin anne ve babaların sorumluluğunda olduğu hatırlatılarak gerekli ilmin tahsili için çocuklarını At Meydanı civarında açılan mektebe göndermeleri istenmektedir. ${ }^{11}$ Zaman içerisinde ibtidaiyeden dârülmuallimât ve inâs sanayi-i nefise mektebine değin her

\footnotetext{
Ali Raşid, "İdare”, Terakkî-i Muhadderât 12 (31 Ağustos 1285/12 Eylül 1869), 1. Ali Raşid, "Evlilik ile Bekârlık”, Terakkî-i Muhadderât 30 (8 Mart 1285/20 Mart 1869), 1. Ali Raşid, "Eşlerin Birbirine Karşı Olan Vazifeleri”, Terakkî-i Muhadderât 38 (10 Mayıs 1285/22 Mayıs 1869), 1. Osman Ergin, Türk Maarif Tarihi (İstanbul: Eser Matbaas1,1977), 1-2: 457-458.

10 Mustafa Şanal, “Osmanlı İmparatorluğu’nda Kız Öğretmen Okulunun (Dârülmuallimât) Kuruluşu, Okutulan Dersler ve Kapatılışı (1870-1924)”, Ankara Üniversitesi Osmanlı Tarihi Araştırma ve Uygulama Merkezi Dergisi 26 (Güz 2009), 225.
}

11 "Vukûât-1 Gayriresmiye", Takvim-i Vekâyi 649 (26 Zilhicce 1278/24 Haziran 1862), 3. 
kademede kız çocuklarına yönelik olarak açılan okullar, kadınların çok yönlü eğitim sürecine ciddi katkılar sağlamıştır. ${ }^{12}$

Gerek kadınlara yönelik ilk süreli yayın olarak kabul edilen Terakkî-i Muhadderât'ta ve gerekse kızlara yönelik ilk mekteplerin açılış gerekçelerinde kızların eğitimi için belirlenen çerçevenin ve hedeflerin kız mekteplerinin müfredat programlarının içeriğinin belirlenmesinde etkili olduğu görülmektedir. Erkek mekteplerinin müfredatında yer alan ortak derslerin yanı sıra kız mekteplerinin müfredatında kadınlı̆̆a müteallik olarak tabir edilen dersler yer almaktadır. İstanbul ve taşradaki eğitimin esaslarının ve içeriğinin düzenlendiği çeşitli nizamname, talimatname ve müfredat programlarında kız ve erkek okullarının müfredat programlarındaki farklılıklar vurgulanmaktadır. 1869 tarihinde yayımlanan Maârif-i Umûmiye Nizamnâmesi'nde erkek rüşdiyeleri ve dârülmuallimîn programından farklı olarak, kız rüşdiyeleri ve dârülmuallimât programında tedbîr-i menzil adıyla bir ders yer almaktadır. ${ }^{13}$ Nizamnâme'ye göre dört yıllık kız rüşdiyesi programında müstakil bir matematik dersi yer almamakta bunun yerine Hesab ve Defter Tutmak Usûlü adıyla bir ders bulunmaktadır. Tarih ve coğrafya dersleri ise Muhtasar Tarih ve Coğrafya olarak birleştirilmiştir. Bunlara mukabil Tedbîr-i Menzil'in programda müstakil bir ders olarak yer alması ve resim dersinin Nakışa Medar Olacak Derece Resim olarak tanımlanması, kız rüşdiyesi müfredatının ev idaresine yararlılık esasına göre düzenlendiğini düşündürtmektedir. ${ }^{14}$

Sıbyan ve rüşdiyelerin birleştirilerek altı yıllık ibtidaiye eğitimine dönüştürüldüğü 1913 tarihli Mekâtib-i İbtidaiye Kanun-ı Muvakkati'nde müfredat programında erkekler için asker talimi, kızlar için ise idâre-i beytiye ve dikiş işleri belirlenmiştir. ${ }^{15}$ Daha sonra yayımlanan altı yıllık ibtidaiye mekteplerine ait bir ders programında da kız mekteplerinde idâre-i beytiye dersi ile birlikte aşçılık dersleri yer alırken erkek mekteplerinde terbiye-i bedeniye, sıhhiye, asker talimi, oyun ve nişan dersi yer almaktadır. ${ }^{16} 1910$ tarihli ön sözünde ibtidaiye ve rüşdiye muallim ve muallimeleri ile bilhassa dârülmuallimîn öğrencilerine yönelik olarak yazdığını ifade ettiği ve her bir dersin nasıl okutulması gerektiğini açıkladığı öğretim yöntemleri kitabında Sabri Cemil, kız ve erkek çocukların bazı ortak derslerinin içeriğinin kız mekteplerinde ev kadınlığına yarayacak şekilde okutulduğunu ifade etmektedir. Sabri Cemil'e göre kız mekteplerinde el işleri dersi, biçki ve dikiş işlerinden başka konuları da kapsamaktadır. Muallime bu derste, "Muntazam bir idâre-i beytiye dersi yapacak değil, fakat genç kızlara birçok amelî mesellerle intizam sevdasını telkin, ev kadını mezâyâ-yı

12 Yükseköğretim seviyesinde olan İnas Sanayi-i Nefise Mektebi 1914 yılında Darülfünun bünyesinde açılmıştır. Bkz. Fatma Ürekli, "Güzel Sanatlar Eğitiminde Osmanlı Hanımlarına Açılan Bir Pencere: İnas Sanayi-i Nefîse Mektebi”, Tarih ve Toplum, 39/231 (Mart 2003), 51.

131869 tarihli Maârif-i Umûmiye Nizamnâmesi, 29. Madde. Bkz. Mahmud Cevad İbnü’l Şeyh Nafi, Maârif-i Umûmiye Nezareti Tarihçe-i Teşkilat ve Ícraatı (İstanbul: Matbaa-i Amire, 1338/1922-1923), 476, 485.

14 Selçuk Akşin Somel, “Osmanlı Modernleşme Döneminde Kız Eğitimi”, Kebikeç 10 (2000), 227.

15 Tedrisat-ı İbtidaiye Kanun-ı Muvakkati (İstanbul, Matbaa-i Amire, 1329/1913), 8.

16 Mekâtib-i İbtidaiye Ders Müfredatı: Altı, Beş, Dört ve Üç Dershane ve Muallimli Mekteplere Mahsus (İstanbul: Matbaa-i Amire,1332/1916-1917), 24-25. 
ciddiyesini temin ve onları abes veya mühlik ezvâktan vikaye etmeye çalışacaktır." ${ }^{17}$ On dokuzuncu yüzyılın ikinci yarısından itibaren ev idaresine yönelik tedbîr-i menzil, idâre-i beytiye, iktisâd-ı beytî, dikiş, nakış, aşçılık ve el işleri gibi derslerin kız mekteplerinin farklı kademelerinde yer aldığı görülmektedir.

\section{Ev İdaresinin Müstakil Bir Alan Olarak Ortaya Çıkışı: Tedbîr-i Menzil}

Ev idaresi öğrenmenin kı çocuklarına yönelik eğitimin önemli bir veçhesi olarak görüldügü gerek on dokuzuncu yüzyıl öncesi geleneksel Osmanlı eğitim anlayışında gerekse yüzyılın ikinci yarısından itibaren kitlesel eğitim programlarında açıkça gözlemlenmektedir. Öte yandan on dokuzuncu yüzyıl öncesinde, daha önce de değinildiği üzere kız çocukları için ev idaresi eğitimi mektepten ayrı tutulmuş ve kız çocukları mektepten belirli günlerde izinli sayılarak evlerinde ve aile ortamında bu eğitimi almışlardır. Kızlara yönelik mekteplerin müfredat programlarına ev idaresi ile ilgili derslerin yerleştirilmesi ile ev idaresi eğitimi tedrisata dâhil olmuştur. Bu minvalde ilk olarak müfredat programlarında adı geçen ders tedbîr-i menzildir. Bu ders, 1869 tarihinde yayımlanan Maârif-i Umûmiye Nizamnâmesi'nde k1z rüşdiyeleri ve dârülmuallimât programında ve 1884 tarihli Klz Sanayi Mektebi Nizamnâmesi'nde beş yıllık programının beşinci senesinde, hıfz-1 sıhha, dikiş, resim ve biçim dersleriyle birlikte programda yer almaktadır. ${ }^{18}$

"Çekip çevirmek ve yönetmek" anlamında kullanılan tedbir ile" ev ya da hane" anlamında kullanılan menzil kelimelerinden oluşan bir tamlama olarak tedbîr-i menzil, ev yönetimi anlamına gelmektedir. İlm-i tedbîr-i menzil ise İslam felsefe geleneğinde ev yönetimi bilgisi olarak ev yönetimi ve aile ahlakı ile ilgili çalışmaların genel adıdır. ${ }^{19}$ Esasında ilm-i tedbîr-i menzil Osmanlı dünyasında yeni bir kavram değildir. Felsefî metotla yazılmış ahlak kitaplarında ev idaresini ve aile ahlakını ifade eden terim olarak kullanılmaktadır. ${ }^{20}$ Bu bağlamda amelî yani pratiğe dönük felsefenin ilm-i ahlak, ilm-i tedbîr-i menzil ve ilm-i tedbîr-i medine olarak zikredilen üç kısmından ikincisini teşkil etmektedir. ${ }^{21}$ Kınalızâde Ali Çelebi, Ahlâk-ı Alầ isimli kitabını bu üç ana başlık altında yazmış ve ilm-i tedbîr-i menzil bölümünde çocukların terbiyesi, söz söyleme, yeme ve içme âdâbı, anne babaya itaat, hizmetlilerin terbiye ve hizmeti gibi aile içi âdâb-1 muâşeret kurallarına yer vermiştir. Kınalızâde bu bölümün girişinde ilm-i tedbîr-i menzilin tanımını yapmaktadır. Ona göre ilm-i tedbîr-i menzil öyle bir ilimdir ki onun ile hanede yaşayan fertler arasında düzenin ve layık olduğu şekliyle geçimi sağlamanın yolları bilinmektedir. Çünkü diğer hayvanlardan ayrı ve üstün bir varlık olarak insana bir arada yaşama mekânı olarak menzil lazımdır ve

17 Sabri Cemil, Amelî Fenn-i Tedris: Dürûs-ı Mütenevvianın Suret-i Tedrisi, Etfâlin Inzibat ve Terbiyesi, İdare-i Mekâtib (Kosova Matbaası, 1326/1910), 53.

18 Ergin, Türk Maarif Tarihi, 688.

19 Sabri Orman, "İlm-i Tedbîr-i Menzil: Oikonomia ve İktisat”, Sosyo-Kültürel Değişme Sürecinde Türk Ailesi içinde (Ankara: T.C. Başbakanlık Aile Araştırma Kurumu, 1992), 265.

20 Mustafa Çağrıcı, “Tedbîrü'l-Menzil”, TDV İslam Ansiklopedisi, c. 40, (Ankara: TDV Yayınları, 2011 ), 260.

21 Orman, “İlm-i Tedbîr-i Menzil: Oikonomia ve İktisat”, 268. 
bu menzil aile fertlerinden, hizmetlilerden ve mülkten ibarettir. ${ }^{22}$ Fakat menzille kastedilen taş ve ağaçla bina olunmuş haneler değil, hanede yaşayan beş unsuru veya fazlasını içeren meskendir. Haneyi meydana getiren bu beş unsur baba, anne, çocuklar, hizmetliler ve iaşedir. ${ }^{23}$ Kınalızâde ayrıca bu bölümde ev idaresinden doğrudan kimin sorumlu olduğunun tayinini de yapmaktadır. Ona göre yönetmek, çekip çevirmek anlamındaki tedbirin öznesi yani müdebbiri menzilin sahibi olan babadır. ${ }^{24}$ İlm-i tedbîr-i menzili bilmek kişiye dünyada efendiliğin ve ahirette saadetinin yolunu açmaktadır. ${ }^{25}$

Kâtip Çelebi de ilm-i tedbîr-i menzili kişiyle eşi, çocukları ve hizmetkârları arasında ortak olan durumların nasıl dengeleneceğini ve dengeden sapmış durumların nasıl düzeltileceğini öğreten ilim olarak tanımlamaktadır. Bu ilim, evde ortaklaşa yaşayan bir topluluğun yararına olan şeylerin bilgisi olup bu sayede kişi dünya ve ahiret mutluluğunu kazanabilmektedir. Kâtip Çelebi'ye göre de menzil kelimesiyle anlatılmak istenen taşlar ve kereste ile yapılan ev değil, koca ile karı, baba ile evlat, hizmet edilen ile hizmet eden ve mal sahibi ile mal arasındaki ilişkidir. Menzile duyulan ihtiyacın sebebi ise insanın yaratılıştan medeni olmasıdır. ${ }^{26}$ Kâtip Çelebi de Kınalızâde gibi insanın medeni olarak doğduğunu ve medeni olarak yaşamayı öğrenmenin ve bilmenin kişiye dünya ve ahiret mutluğunun yolunu açtığını vurgulamaktadır.

Doğuştan medeni olan insanın aile ve toplum içerisinde yaşamaya duyduğu ihtiyaç ve bunun için öğrenmesi gerekenler, on dokuzuncu yüzyıldan itibaren ahlakın konusu olmaktan çıkıp birer müstakil alan olarak beliren âdâb-1 muâşeret, ${ }^{27}$ malumat-1 medeniye ${ }^{28}$ ve ev idaresi literatürlerinin ve bu alanlarda verilen eğitimin başlıca gerekçesini ve konusunu oluşturmaktadır. Kişinin toplum içerisinde görgü kurallarına uyması, yurttaş olarak sorumluluklarına riayet etmesi ve evinin fiziksel koşullarını ve aile fertleriyle olan ilişkisini belirli kriterlere göre düzenlemesi, kişi için mutluluğun teminatı olarak görülmektedir. Öte yandan dünya ve ahiret saadetine vurgu yapan önceki dönem ahlak kitaplarının aksine bu kitaplarda mutluluk, kişinin malumatına ve davranışlarına bağlı olarak yaşadığı aile ve toplumda elde edeceği dünyevi bir mutluluktur.

On dokuzuncu yüzyılın ikinci yarısından itibaren ev idaresi ile ilgili olarak tedbîr-i menzil kavramının kız mekteplerinin müfredat programında ev idaresi ile ilgili kitap ve yayınlarda kullanılmaya devam edildiği görülmektedir. Mehmed Rıfat'ın 1303/1885-1886 tarihli

22 Kınalızâde Ali Çelebi, Ahlâk-ı Alậ̂, haz. Mustafa Koç (İstanbul: Klasik Yayınları, 2007), 325.

23 Erkân-1 menzil beştir: peder, mader, ferzend, hâdim, kût. Kınalızâde Ahlâk-ı Alâî, 328. Beşinci unsur olarak zikredilen kût yaşamak için yenilen şey, yiyecek anlamına gelmektedir. Ferit Devellioğlu, Osmanlıca-Türkçe Ansiklopedik Lûgat (Ankara: Aydın Kitabevi, 1998), 529.

24 Kınalızâde, Ahlâk-ı Alậ, 328.

25 Kınalızâde, Ahlâk-ı Alâi, 325.

26 Kâtip Çelebi, Keş̧ü 'z-Zünûn (Dersaadet: Alem Matbaası, 1310/1892), 270.

27 Âdâb-1 muâşeret literatürü için bkz. Fatma Tunç Yaşar, Alafranga Halleri: Geç Osmanlı'da Âdâb-ı Muâşeret (İstanbul: Küre Yayınları, 2016).

28 Malumat-1 ahlakiye ve medeniye ders kitaplarıyla ilgili detaylı tartışma için bkz. Fatma Tunç Yaşar, "II. Meşrutiyet Döneminde Yurttaşlık, Ahlak ve Medenilik Eğitimi: Malumat-1 Medeniye Ders Kitapları”, Osmanlı Araşttrmaları / Journal of Ottoman Studies 52 (2018), 311-342. 
Tedbîr-i Menzilden Hane Bahsi isimli kitabı ev idaresini konu alan müstakil bir çalışmadır. Kitabın kapağında ya da içeriğinde ders kitabı olduğuna dair bir işaret bulunmamakla birlikte, Mehmed Rıfat'ın kısa ve öz bahislerden oluşan kitabı bir ders kitabı formatını çağrıştırmaktadır. Nitekim kitabın yazıldığı tarihte kız mekteplerinin ders programında böyle bir ders mevcuttur ve bu isimle yazılmış başka bir ders kitabı gözükmemektedir. Bununla birlikte hem ders kitabı hem de genelin istifadesine sunulmuş bir kitap olma ihtimali de söz konusudur. Mehmed Rıfat'ın kitabının giriş kısmı Kınalızâde'nin ahlak kitabında ilm-i tedbîr-i menzil başlıklı bölüme yazdığ 1 giriş ile oldukça benzerdir. Bu bölümde Mehmed Rıfat, insanın doğuştan medeni olduğunu, bir meskene ihtiyaç duyduğunu ve insanın bu meskeni idare etmenin yollarını bilmesi gerektiğini vurgulamaktadır.

İnsan ki, medeni bi’t-tabdır herhalde bir mevâya muhtaçtır. Bir mevâ ki insana mahsustur. Bir takım şerâit ve tedâbir-i medeniyi cami bulunması çaresizdir. Bu şerâit ve tedâbir insana muhafaza-i sıhhatle beraber istihsal-i refah ve maişete vabeste birçok vesait-i medeniyedir ki, bu risalenin mevzuu onları tarif ile umûr-1 beytiyeyi tedbîr ve teshil etmekten ibarettir. ${ }^{29}$

Mehmed Rıfat kitabında sırasıyla hanenin esası, sağlık, mefruşat, hizmetlilerin durumu ve onlara yönelik davranış, aydınlatma, ısıtma, hanelerde görülebilecek hayvanlarla mücadele ana başlıkları altında çok sayıda konuya yer vermektedir. Mehmed Rıfat bu konuları dönemin bilimsel, pedagojik ve medeni muâşeret kurallarını göz önünde bulundurarak açıklamaktadır. Örneğin "Mefruşat ve Teferruatı" ana başlığı altında salonu ele aldığı bölümde tasvir ettiği salon dekorasyonu Ahmed Midhat'1n Avrupa Âdâb-ı Muâşereti Yahud Alafranga isimli âdâb-1 muâşeret kitabında anlattığı alafranga salon ile birçok açıdan benzerdir. ${ }^{30}$ Öncelikle Mehmed Rıfat, Osmanlı hanesi için çok da uzun bir geçmişi olmayan salondan bahsetmektedir. $\mathrm{Bu}$ salonda biri üzeri edebi ve sanatsal eserler ile süslenmiş iki masa, bir büyük ayna, kanepe, koltuk ve sandalyeler yer almakta ve salonun duvarında güzel bir saat, haritalar, termometre asılı bulunmaktadır. ${ }^{31}$ Mehmed Rifat'ın ev idaresi standartları ve prensipleri konusunda referans noktası da medeni devletler ve toplumların yaşayışlarıdır. Örneğin ev idaresinin en önemli konularından olan sağlık konusunda referansı memâlik-i mütemeddinedir. Ona göre medeni devletlerde sağlık konusuna devlet ehemmiyet gösterdiği gibi hane içerisinde sağlığa ev müdürleri fevkalade dikkat göstermektedirler. ${ }^{32}$ Mehmed Rıfat, evin bölümleri ve oda sayısını da maîşet-i medeniyeye mukteza hanelere göre vermektedir. ${ }^{33}$

Geç dönem Osmanlı' da ev idaresi için tedbîr-i menzil kavramını kullanan bir başka isim de Mehmed İzzet’tir. Mehmed İzzet'in konusunu ilm-i tedbîr-i menzil olarak tanımladığı ve

29 Mehmed Rıfat, Tedbîr-i Menzilden Hane Bahsi (İstanbul: Mihran Matbaası, 1303/1885-1886), 4.

30 Ahmed Midhat'a göre alafranga usûle göre döşenmiş bir salonun en vazgeçilmez mobilyası salonun orta yerindeki büyük masadır. Bu masanın üzerine ya da madamın koltuğuna yakın diğer masalardan birinin üzerine yeni çıkmış olan kitaplardan bazıları, edebi mecmuaların son nüshaları ve o günkü gazeteler konulmaktadır. Ahmed Midhat, Avrupa Âdâb-ı Muâşereti Yahud Alafranga (İstanbul: İkdam Matbaası, 1312/1896-1897), 285.

31 Mehmed Rifat, Tedbîr-i Menzilden Hane Bahsi, 34.

32 Mehmed Rifat, Tedbîr-i Menzilden Hane Bahsi, 19.

33 Mehmed Rıfat, Tedbîr-i Menzilden Hane Bahsi, 29. 
ilk cildi 1901 yılında Rehber-i Umûr-ı Beytiye ismiyle yayımlanan üç ciltlik ev ansiklopedisi, ev idaresine yeni bir perspektif getirmektedir. ${ }^{34}$ Mehmed İzzet, ansiklopedinin giriş bölümünde bu eserin ev ile ilgili bilcümle iş ve hususun rehberi olmak üzere memleketin önemli ihtiyaçları göz önünde bulundurularak ev ansiklopedisi tarzında kaleme alındığını ve içerdiği madde ve makalelerin doğrudan doğruya ya da dolaylı olarak ev işleriyle alakalı olduğunu ifade etmektedir. ${ }^{35}$ Mehmed İzzet, ayrıca bu bölümde ansiklopedide ele alınacak konuları sıraladıktan sonra kitabın konusunu "İlm-i tedbîr-i menzil" olarak belirlemekte ve ilm-i tedbîr-i menzilin tanımını yapmaktadır.

İlm-i tedbîr-i menzil yani talim ve terbiye-i nevzâd ile bir ailenin âşiyâne-i huzur ve saadeti olan hanenin hüsn-i idâresi usûlü, tabâbet-i beytiye, ev eczahanesi, ev eşyasının suret-i muhafazası ve tanzimi, evde bulunan gümüş, altın ve maden-i saireden mamul avâni-i zikıymenin suret-i tathiri ve cilalandırılması, aşç1ık, eve müteallik hıfz-1 sıhha, ilm-i hikmet-i tabiiyenin eve kabil tatbik bulunan aksamına dair malumat, tezyinât-1 nisaiyeden madud bulunan tuvalet usûlü ve tuvalet takımları, pomadeler, elbise biçmek ve dikiş envaı ve hakeza mevâd-1 muhtelifeye müteallik mebâhis-i mütenevvia. ${ }^{36}$

Mehmed İzzet, ilm-i tedbîr-i menzilin konusunu kısaca ailenin yaşam alanı olan hanenin güzel bir suretle idare edilmesi için ev ile ilgili olabilecek her türlü konuya dair malumat olarak tanımlamaktadır. "Re "Rber zekûr ve inâsdan herkese lazım bir kitap olmak hasebiyle mündericatı da ona göre tertib ve tahrir kılınmıştır."38 sözleriyle de Mehmed İzzet, hedef okuyucu kitlesini kadın ve erkek fark etmeksizin herkes olarak belirlemektedir. Mehmed İzzet'in ev ansiklopedisinin sadece evi konu alan içeriği, alfabetik sıra ile maddeler olarak düzenlenen formatı ve ev idaresi ile ilgili işlerin muhatabı olarak belirlediği genel okuyucu kitlesi, onun ilm-i tedbîr-i menzili, önceki dönemlerin ahlak kitaplarında olduğundan farklı bir bağlamda ele aldığını göstermektedir. Nitekim Kınalızâde ve Kâtip Çelebi menzilden kastın evin maddi özellikleri olmadığını vurgularken, Mehmed İzzet ansiklopedisinde inşasında kullanılan malzemesi, çatısı, odaları, mutfağı, ışık alan pencereleri, duvarları ve eşyalarıyla maddi olarak evi konu almaktadır.

Mehmed Rıfat'ın ve Mehmed İzzet'in tedbîr-i menzili konu alan bu eserlerinde ev idaresi müstakil bir alan olarak tanımlanmakta ancak evin idarecisinin kim olduğu tanımlanmamaktadır. Öte yandan, evin maddi özellikleri ve ev işlerinden ziyade ilişkilerin merkeze alındığı ahlak kitaplarının ilm-i tedbîr-i menzil bölümlerinde tedbîr-i menzilden evin

34 Mehmed İzzet, Rehber-i Umûr-ı Beytiye (Dersaadet: Feridiye Matbaası, 1319/1901). İlk cildin İfade-i Meram k1smının sonunda tarih "fi gurre-i Muharrem 1319" (20 Nisan 1901) olarak verilmektedir. Ansiklopedinin ikinci cildi gurre-i Rebîülevvel 1320'de (10 Nisan 1902) ve üçüncü cildi gurre-i Ramazan 1326'da (27 Eylül 1908) yayımlanmıştır.

35 Mehmed İzzet, "İfade-i Meram", i-ii.

36 Mehmed İzzet, Rehber-i Umûr-l Beytiye, iii.

37 Rehber-i Umûr-l Beytiye'de yer alan maddeler ve konu tasnifi için bkz. Nilüfer Bayülgen Baran, Rehber- $i$ Umur-l Beytiye: A Guideline in the Socialization of Female Students at the Turn of the Twentieth Century (Yüksek Lisans tezi, Boğaziçi Üniversitesi, 1998).

38 Mehmed İzzet, Rehber-i Umûr-ı Beytiye, ii. 
reisi olan baba sorumludur. Mehmed İzzet, ansiklopedisini kadın ve erkek herkes için kaleme aldığını belirtmekte, Mehmed Rıfat da doğrudan bir ev idarecisi tanımı yapmamaktadır. Bununla birlikte Mehmed Rıfat, herkesin bir yuva açıp aile kurmayı arzu edeceğini gerek kendi rahatı gerekse aile fertlerinin sıhhat ve refahı için her şeyden önce güzel bir mesken tedarikine mecbur olduğunu ifade etmekte ve hane sahibinin servetine uygun olarak bir hane seçmek durumunda kaldığını ifade etmektedir. ${ }^{39}$ Bu noktadan bakıldığında Mehmed Rıfat'ın evin idarecisi olarak erkeği ima ettiği söylenebilir. Ancak yine de kitabın beslenme ve sağlıktan ev düzenine ve rutin ev işlerine varıncaya kadar kapsamlı içeriğine ve kullanılan dile bakıldığında Mehmed İzzet'in ev ansiklopedisi gibi umumun istifadesi gözetilerek hazırlanmış bir kitap olması muhtemeldir.

\section{Kız Mekteplerinde İdâre-i Beytiye Dersleri}

1890’lı y1llarda eğitim çevrelerinde ve süreli yayınlarda kı mekteplerinin müfredat programının nasıl olması gerektiğine dair ciddi tartışmalar mevcuttur ve bu tartışmalar o zamana kadar belirli bir rehbere tabi olmayan müfredat programlarının düzenlenmesine vesile olmuştur. Nitekim 1870 yılından itibaren eğitim veren dârülmuallimât ancak 1895 yılında yapılan bir düzenleme ile planlı bir müfredat programına sahip olmuştur. Bu programda ev idaresi ile ilgili olarak idâre-i beytiye ismiyle müstakil bir ders yer almaktadır. ${ }^{40} \mathrm{Bu}$ tarihlerden itibaren rüşdiye ve dârülmuallimât müfredat programlarında ve diğer yayınlarda tedbîr-i menzil yerine yine ev idaresi anlamına gelen idâre-i beytiye ifadesinin tercih edildiği ve aynı isimle müfredata uygun ders kitapları yayımlanmaya başlandığı görülmektedir. ${ }^{41}$ Her ne kadar tedbîr-i menzil ve idâre-i beytiye benzer anlamlara gelse de daha önce tartışıldığı üzere tedbîr-i menzil on dokuzuncu yüzyıl öncesinde felsefe ve ahlak bağlamında kendine özgü bir anlam dünyasına sahiptir. Öte yandan modernleşme ve medenileşme girişimleri çerçevesinde müstakil bir alan olarak ortaya çıkan ve önem kazanan ev idaresi için Osmanlı dünyasında önceleri literatürde hâlihazırda mevcut olan bir kavram ile yetinilmiş ancak alanın müstakiliyeti ve ahlaktan bağımsız maddi ve dünyevi boyutu yeni bir kavram kullanmayı gerektirmiş gibi gözükmektedir. Nitekim Uğur Tanyeli, Tanzimat okullarında okutulan ilmihal niteliğindeki doğru davranış rehberleriyle karşılaştırıldığında sonraki dönemlerin idâre-i beytiye ders kitaplarının ailenin iç ilişkilerini, görev ve sorumluluklarını ve duygusal

39 Mehmed Rifat, Tedbîr-i Menzilden Hane Bahsi, 5-6.

40 Dârülmuallimât ile İhtiyat Kısmına Mahsus Talimatname (İstanbul: Matbaa-i Amire, 1313/1897-1898). Bu talimatname, ders programı ile birlikte tam metin olarak 1318 tarihli Salnâme'de yer almaktadır. Salnâme-i Nezaret-i Maârif-i Umûmiye (İstanbul, Matbaa-i Amire, 1318/1900-1901), 311.

41 Bunlardan bazıları şunlardır: Ali Rıza, Kızlara Mahsus İdare-i Beytiye (Birinci Kitap) (İstanbul: Karabet Matbaası, 1315/1899-1900); Ali Riza, Kızlara Mahsus İdare-i Beytiye (İkinci Kitap) (İstanbul: Karabet Matbaas1, 1315/1899-1900); Ali Riza, Kızlara Mahsus İdare-i Beytiye (İstanbul: Karabet Matbaası, 1323/1907-1908); Behram Münir, Muhtasar İdare-i Beytive (İstanbul: A. Asaduryan Sirket-i Mürettibiye Matbaası, 1321/19051906); Hüseyin Hıfzı, Tarz-l Nevin İdare-i Beytiye (Dersaadet: Arakis Matbaası, 1330/1914-1915); Mehmed İzzet ve Nazım, İdâre-i Beytiye (İstanbul: Kanaat Kütüphanesi, 1330/1914-1915; Melekzâde Fuad, Vezâif-i Beytiyeden Hanımlara Mahsus Aile Dersleri (Dersaadet: Şirket-i Mürettibiye Matbaası, 1325/1909-1910); Nazım, İdâre-i Beytiye (İstanbul: Garoyan Matbaası, 1334/1918) ve Nazım, İdâre-i Beytiye (Hilal Matbaası, 1335/1919-1920). 
bağlarını tanımlayan seküler ders kitapları olduğunu ifade etmektedir. ${ }^{42}$ Öte yandan idâre-i beytiye, on dokuzuncu yüzyılın sonlarından itibaren sadece bir dersin ismi olarak değil, ev idaresi anlamına gelen genel bir ifade olarak Osmanlı yayın dünyasında yaygınlık kazanmıştır.

Kız mekteplerinin farklı kademelerinde okutulmak üzere yayımlanan idâre-i beytiye kitaplarında ele alınan konular Mehmed Rıfat'ın Tedbîr-i Menzil'den Hane Bahsi kitabıyla büyük benzerlikler göstermekle birlikte, idâre-i beytiye ders kitaplarında ev idaresinden doğrudan kadınlar sorumlu tutulmakta ve bu kitaplar genellikle kız çocuklarına hitaben yazılmaktadır. İdâre-i beytiye ders kitapları, ev kadınlarına ev idaresi hakkında bilinmesi gereken hususları açıklamakta ve günlük ev işlerinin nasıl yapılması gerektiğine dair bilgiler içermektedir. Melekzâde Fuad, kız mekteplerinde okutulmak üzere yazdığı Vezâif-i Beytiyeden Hanımlara Mahsus Aile Dersleri kitabında ev işlerinden sorumlu olarak evin hanımını görmekte, hizmetçiler olduğunda dahi bazı işleri kesinlikle evin hanımının yapması gerektiğini, diğer işleri ise hizmetçiler yapsa dahi başlarında bulunması gerektiğini ifade etmektedir. ${ }^{43}$ Behram Münir de ibtidaiyeler için yazdığ 1 Muhtasar İâre-i Beytiye ders kitabının giriş bölümünde, ilk terbiyenin annelerden alınacak olması dolayısıyla kadınların iffet, istikamet ve güzel ahlak ile donanmış olmalarının ve idare edecekleri hanelerin her türlü ihtiyacına vakıf olmalarının fayda ve güzelliklerinin aşikâr olduğunu ve kadınların bu sayede mutluluk ve istirahat içinde bir ömür geçireceklerini ifade etmektedir. Ona göre kadınların söz konusu husustaki vazifelerini daha mektep sıralarında öğrenmelerinin zorunluluğunu izah etmeye gerek dahi yoktur. ${ }^{44}$ Behram Münir, iyi bir ev hanımının bulunduğu haneyi iyi idare etmesi için büyük ve küçüklere nasıl muamele edeceğini, yemek pişirmeyi, çamaşır yıkamayı, kola, ütü yapmayı, sofra tertibini ve usûl-i defter-i beytî denilen defter tutmayı bilmesi gerektiğini vurgulamaktadır. ${ }^{45}$

Hüseyin Hıfzı, altı yaşından on yaşına kadar olan kız çocukları için kaleme aldığını ifade ettiği Tarz-ı Nevin İdâre-i Beytiye kitabında bir kız çocuğunun ev hanımı olarak eğitimini konu almaktadır. Kitapta sekiz yaşında bir kız çocuğu olan Mediha karakteri üzerinden ev idaresine yönelik dersler anlatılmaktadır. Mediha mektebe gitmektedir ve tüm aile fertlerinin olduğu gibi Mediha'nın vazifeleri vardır. Bu vazifeler ona gelecekte kendi evini yönetme becerisini kazandırmayı amaçlamaktadır. Dersler, Mediha’nın ev işlerini öğrenmesine yöneliktir. Kitabın son başlığı ise "Iyi Bir Ev Hanımı Nasıl Olmalıdır?" sorusudur. Bu soru annesinin Mediha'ya tavsiyeleri üzerinden cevaplanmaktadır. Annesi iyi bir ev hanımı olmak için ev işleri dışında bilmesi gerekenleri öğüt olarak kendisine sıralamaktadır. Buna göre iyi bir ev hanımı olmak için evin tertip ve düzenini, temizliğini bilmek kâfi değildir. Ev hanımı, modaya kapılıp beyhude para harcamamalı, evin kazancı nispetinde harcama yapmayı bilmelidir. Ve

42 Uğur Tanyeli, İstanbul'da Mekan Mahremiyetinin İhlali ve Teşhiri: Gerilimli Bir Tarihçe ve 41 Fotoğraf (İstanbul: Akın Nalça Kitapları, 2012), 47-48.

43 Melekzâde Fuad, Vezâif-i Beytiyeden, s. 99.

44 Behram Münir, Muhtasar İdare-i Beytiye, 3-4.

45 Behram Münir, Muhtasar İdare-i Beytiye, 36-37. 
kitap adeta bir masal kitabı gibi sona ermektedir. Mediha büyümüş, mektepten mezun olmuş, ev işlerinde ablası kadar ilerlemiş, "hamarat, dikkatli, her iş elinden gelir bir ev hanımı" olmuştur. "Annesinin nasihatlerini unutmayan Mediha şimdi mesut bir ailenin validesidir."

İdâre-i beytiye ders kitaplarında, ahlak kitaplarının ilm-i tedbîr-i menzil bölümlerinde olduğu gibi hanenin iyi idare edilmesi ile aile saadeti arasında doğrudan bir ilişki kurulmaktadır. Hüseyin Hıfzı ders kitabında ilk olarak aile konusunu ele almakta ve aileyi "Anne, baba, büyükanne, büyükbaba, ağabey, abla, küçük kardeş gibi bir arada bulunanlar" olarak tanımlamaktadır. ${ }^{47}$ Ona göre ailede herkesin bir vazifesi vardır ve herkes bu vazifesini hakkıyla ifa ettiğinde "aile ocă̆l cennet bucă̆ l!" ${ }^{48}$ olma potansiyeline sahiptir. Hüseyin Hıfzı'nın ev içerisinde öngördüğü iş bölümünde aile reisi babadır ve ailenin geçimini sağlamaktan sorumludur. Kadın ise evin düzenini sağlamak, çocukları yetiştirmek ve terbiye etmekten sorumludur. Nitekim Hüseyin Hıfzı'ya göre “Terbiyesiz, arsız çocukların çektikleri zahmetler, meşakkatler hep annelerinin yüzündendir. Bunların anneleri ya çocuklarının terbiyesinde tembellik etmişsir yahut kendi de anne terbiyesi görmediğinden çocukları da terbiyeden aciz kalmıştır." ${ }^{49}$

Klasik dönem ahlak kitaplarının tedbîr-i menzil bölümlerinde evin idarecisi ve evin reisi aynı kişi yani evin geçimini sağlayan erkek iken geç dönem idâre-i beytiye ders kitaplarında evin idarecisi kadın, evin reisi ise yine evin geçiminden sorumlu olan erkektir. Kadın, evde gündelik hayatın düzenlenmesi için gerekli tüm işlerin yapılmasından ve organize edilmesinden sorumludur. Kadının evi iyi idare etmesi eşine karşı bir sorumluluğu olarak görülmektedir. Melekzâde Fuad'a göre “Erkeğin önüne o kadar masrafa karşı tatsız bir yemek konursa hiddetini celb edeceği tabiidir. ${ }^{50}$ Melekzâde Fuad, ahlak, âdâb-1 muâşeret ve ev idaresi konularını birlikte ele aldığı kitabında evdeki iş bölümü ve eşlerin birbirleriyle olan ilişkilerini geleneksel ve dini referanslarla tanımlamaktadır. Buna göre erkek evin geçimini sağlamakla büyük bir sorumluk yüklenmiştir ve kadın evde eşinin ve ailesinin istirahatini sağlamakla vazifelidir.

\section{Mektepte İlmî ve Fennî Ev İdaresi Eğitimi}

Ev idaresine yönelik olarak hazırlanan ders kitaplarında ev idaresi mektepte öğrenilmesi gereken fenlerden biri olarak tanımlanmaktadır. Özellikle sultani mektepleri ve dârülmuallimât gibi daha üst kademeler için kaleme alınan ders kitaplarında ev idaresi ve ilgili konular bilimsel açıdan ele alınmaktadır. Dârülmuallimât ve Sanayi-i Nefîse muallimesi olan Ayşe Sıdıka, Usûl-i Talim ve Terbiye isimli kitabında öğretmenlerin birçok alanda bilgi sahibi olması gerektiğini ifade etmekte ve bu alanlardan biri olarak Terbiye-i Cismâniye (Beden ve Sağlık Eğitimi) başlığı altında idâre-i beytiye konusunu ele almaktadır. ${ }^{51}$ Ayşe Sıdıka, idâre-i

\footnotetext{
46 Hüseyin Hıfzı, Tarz-ı Nevin İdare-i Beytiye, 93-94.

47 Hüseyin Hıfzı, Tarz-ı Nevin İdare-i Beytiye, 4.

48 Hüseyin Hıfzı, Tarz-ı Nevin İdare-i Beytiye, 5.

49 Hüseyin Hıfzı, Tarz-ı Nevin İdare-i Beytiye, 8.

50 Melekzâde Fuad, Vezâif-i Beytiyeden, 98-99.

51 Ayşe Sıdıka, Usûl-i Talim ve Terbiye (İstanbul: Âlem Matbaası, 1313/1895-1896), 39.
} 
beytiyenin başlıca konularından biri olan beslenme konusu çerçevesinde bu ilmi öğrenmenin ne kadar elzem olduğunu tartışmaktadır. Ona göre "Adeta bir makinenin hareket etmesi ve bir iş, bir hizmet yapabilmesi için kömür ve su ne kadar lazım ise bir insanın da hareket ve faaliyette bulunarak gerek kendisi için gerekse saireleri için bir iş ve hizmet görmesi ancak yemek yemesiyle olabilir. [...] Binaenaleyh bir insan ne kadar iyi beslenirse o kadar iyi iş görebilir." 52 Bu tanımlamada Ayşe Sıdıka, insanı bir makineye benzetmekte ve yemek yemeye faydası açısından yaklaşmaktadır. Ona göre bu ilim sayesinde kişi hangi miktarda, hangi besinlerden ve günün hangi saatlerinde yemesi gerektiğini öğrenmekte ve bu sayede hareket faaliyetini düzenleyerek gününü verimli geçirebilmektedir. Ayşe Sıdıka, yine elbise konusunu da moda ve muâşeret perspektifinden ziyade temizlik ve sağlık açısından ele almakta, kadınların süslenmek uğruna dar ve sağlıksız elbise giymelerini eleştirmektedir. Ona göre "Elbise, evvel emirde soğuk gibi, sicak gibi, çamur ve yağmur gibi tesîrât-ı hariciyeden bedeni muhafaza etmek içindir." "53 Ayşe Sıdıka için idâre-i beytiyenin bir fen olarak en temel iki prensibi bilimsellik ve fonksiyonelliktir. Esasında döneminin ilk pedagojik ders kitaplarından birini kaleme alan Ayşe Sıdıka, on dokuzuncu yüzyılın son çeyreğinde devletin ortaya koymaya çalıştığı eğitim politikasını yansıtmaktadır. Selçuk Akşin Somel'e göre Osmanlı eğitim modernleşmesinin bu dönemde başlıca iki hedefi vardır. Bunlar pragmatik ve doğa bilimlerini içeren bir müfredatla eğitim sunabilen bir okul sistemimin kurulması ve genel eğitimin vilayetlerde yayılmasıdır. ${ }^{54}$ Gerek rasyonel, pragmatik ve fonksiyonel içeriğiyle idâre-i beytiye dersi gerekse merkez ve vilayetlerde açılan okullarla kızların eğitim sürecine dahil edilmesi bu iki hedef ile uyumluluk arz etmektedir.

Birçok idâre-i beytiye ders kitabının yazarı olan Nazım, inâs sultanisinin altıncı senesiyle dârülmuallimât ve kız sanayi mekteplerinde okutulmak üzere hazırladığ́ Amelî ve Nazarî İktisâd-ı Beytî ders kitabında, idâre-i beytiye ile eş anlamlı olarak kullandığı iktisâd-ı beytîyi ev ve aile işlerinden bahseden bir ilim olarak tanımlamaktadır. Ona göre "İlm-i beyt", "ilm-i aile", ilm-i tedbîr-i menzil" gibi isimlerle anılan bu ilim kızlara kadınlık vazifelerini öğretmekte, aileye ve vatana nasıl hizmet edeceklerini göstermektedir. İktisâd-1 beyti ifadesindeki iktisâd kelimesi idare ve tasarruf yani ev işlerini âkilâne ve müdebbirâne tanzim etmek anlamına gelmektedir. ${ }^{55}$ Nazım, iktisâd-ı beytî tanımında olduğu gibi kitabının birinci konusu olarak ele aldığ 1 "ev kadını" tanımlamasında da "âkilâne" ifadesini kullanmaktadır. Ona göre "Bir meskenin selameti kadının âkilâne harekâtına tabidir." "56 Nazım'ın akıllıca anlamına gelen âkilâne ile kastettiği şey ise ev idaresinde rasyonel ve bilimsel prensiplere riayet etmektir.

İnas sultanisinin altıncı sınıfında okutulmak üzere hazırladığı İktisâd-ı Beytî ders kitabında Ahmed Edib de idâre-i beytiyeyi bir fen olarak tanımlamakta ve gelişigüzel ev idaresinin

52 Ayşe Sıdıka, Usûl-i Talim ve Terbiye, 40.

53 Ayşe Sıdıka, Usûl-i Talim ve Terbiye, 44

54 Selçuk Akşin Somel, Osmanlı'da Eğitimin Modernleşmesi (1839-1908): Íslamlaşma, Otokrasi ve Disiplin (İstanbul: İletişim Yayınları, 2010), 334.

55 Nazım, Amelî ve Nazarî İktisâd-ı Beytî (Dersaadet: Kitabhane-i İslam ve Askeri, 1334/1918-1919), 13.

56 Nazım, Amelî ve Nazarî İktisâd-ı Beytî, 6. 
sakıncalarının artık bilindiğini ifade etmektedir. "Idare-i beytiyenin bugün bir fen hükmüne girip mekteplerde hanım kuzlara tahsil ettirilmesi, şimdiye kadar olduğu gibi bir hanenin gelişi güzel bir surette idaresinin ve cehaletle ev müdireliği etmenin mahzurlarl görülmesindendir. Bir evi idare demek evde iktisâdın, slhhatin, neşenin temini demektir." ${ }^{77}$ Ahmed Edib'e göre iktisâd-1 beytî, fenn-i idâre-i beytiye anlamına gelmektedir ve bu fen "Hıfz-ı slhha, ilm-i iktisâd, ulûm-l tabiiyenin birçok şubelerinden kendisine lazım olan malumatı alarak toplanmış ve bunlardan teşkil etmiştir." ${ }^{58}$ Ona göre bu fenni öğrenmek kız çocukları için önem arz etmektedir. Mektep sıralarından sonra ev idaresi sorumluluğunu yüklenecek olan kadın ancak bu fen sayesinde gayret ile servet kazanmayı ve kazanılmış serveti iyi idare etmeyi bilecek, evinin idaresini yoluna koyacak, temizlik, nezafet, hıfz-1 sıhha yollarını bilecek, çocuklarını yetiştirme, terbiye etme yollarını öğrenecektir. Ahmed Edib'e göre kız çocuklarının mektepte eğitimi ve terbiyesinin en önemli gayesi ev idaresi öğrenmektir. Nitekim her genç kız idâre-i beytiye fenninin ve iktisâd-ı beytî derslerinin gerektirdiği malumatı kendisine verecek bir valideye sahip olmayabilmektedir. Bu noktadan hareketle de ev idaresinin geçmişte olduğu gibi bir valide yanında ya da aile ortamında öğrenilebileceğini düşünenleri eleştirmektedir. Ona göre "İdâre-i beytiyenin bir fen olduğunu bilmeyenler [idâre-i beytiyenin] ayrı a tahsile muhtaç olmayıp evde amelî olarak ögrenilebileceğini ve mektebin yalnız okumayı, yazmayı ve imtihanda lazım olacak, memuriyetlerde işe yarayacak diğer fenleri öğretip ev işlerini evde ögrenmeye terk etmek lazım geleceğini söylerler. Bir aile içerisinde talim olunabileceğini iddia ederler." 59

Ev idaresi derslerinin müfredat programlarında fenne dayalı bir ev kadınlığı dersi olarak ele alındığı görülmektedir. Kız mekteplerinin neredeyse tüm kademelerinde okutulan bu ders, kız çocuklarına ev kadınlığını öğretmekte ve ideal ev kadını profilini çizmektedir. İdâre-i beytiye ve iktisâd-ı beytî ders kitaplarında ev kadınlığı profesyonel anlamda ele alınmakta, ev kadını evinde adeta genişletilmiş bir mesai anlayışı içerisinde hizmet vermektedir. Evde hangi gün hangi iş ya da işlerin yapılacağı bir program çerçevesinde belirlenmektedir. Bu programı belirleyen işler genellikle çamaşır yıkama, ince temizlik, ziyaret kabulü, gezmeye gitmek, ütü gibi şeylerdir. $\mathrm{Bu}$ gibi işler için evin kalabalıklığına ve durumuna göre haftada bir ya da iki hafta bir olmak üzere belirli bir gün tayin edilmesi ve o işin hep aynı gün yapılması istenmektedir. Örneğin ev kadınının haftada bir günü çamaşır günü olarak tayin etmesi ve o gün hizmetçiler işi yapacak dahi olsa başlarında bulunması, hizmetçilere yıkanacak çamaşırları renklerine göre ayırarak vermesi, güneşte ve gölgede kuruması gereken çamaşırları ayırt etmesi gerekmektedir. ${ }^{60}$ Yine evin süpürülmesi için yatak odasından başlanılarak bir sıra tayin edilmekte, evdeki diğer işler de hijyen ve sağlık kuralları çerçevesinde düzenlenmektedir. ${ }^{61}$ İdâre-i beytiye ders kitaplarında ev kadını evin tüm düzeninden sorumlu kişi olarak görülmektedir. Bu nedenle ev kadını evde

57 Ahmed Edib, İktisâd-ı Beytî (İstanbul: Kanaat Kütüphanesi, 1331/1915-1916), 3.

58 Ahmed Edib, İktisâd-ı Beytî, 29.

59 Ahmed Edib, İktisâd-ı Beytî, 30.

60 Ahmed Edib, İktisâd-ı Beytî, 37-38.

61 Ali Riza, İdare-i Beytiye (1315/1899-1900), 32. 
tamamıyla istirahatin temin edildiğine, kapıların kapandığına, soba gibi tehlikeli şeyler varsa onların yoluna konduğuna emin olduktan sonra yatmalı ve hane halkı kalktığında her şeyin muntazam olması için onlardan önce uyanmış olmalıdır. ${ }^{62}$

Öte yandan idâre-i beytiyenin bir fen olarak öğrenimi mekteple sınırlı gözükmemektedir. On dokuzuncu yüzyılın ikinci yarısından itibaren ev idaresini ilmî ve fennî olarak ele alan kitap, dergi ve ansiklopedi olmak üzere çok sayıda yayın mevcuttur. Bunlardan bir kısmı kadınlara yönelik olarak hazırlanan kadın dergileri iken bir kısmı idâre-i beytiyeyi kadın ya da erkek herhangi birinin değil, genel olarak umûmun yarına bir fen olarak ele almaktadır. Daha önce de zikredilen Mehmed İzzet'in Rehber-i Umûr-ı Beytiye'si ev işlerine dair bir rehber aile ansiklopedisidir. Yine ilk sayısı 1913 yılında yayımlanan Âfiyet dergisi "Mesâil-i sıhhiyeden maada idâre-i umûr-ı beytiyeden, para biriktirmekten, kadınlara ait el işlerinden, yemek pişirmekten gayet sade bir lisan ile her türlü mesâil-i fenniyeden bahs eder." bir dergi olarak idâre-i beytiye ders kitaplarında yer alan konuları ele almaktadır. ${ }^{63}$ Ayrıca dergi kapağında yer alan "Sağllk ve ev idaresi ile ilgili konularda her türlü soru sorulabilmektedir." ibaresiyle okuyucuyu ile interaktif iletişime geçmektedir. Dolayısıyla oldukça kapsamlı bir alan olan ev idaresini bir fen olarak öğrenmek isteyen herkes kadın ya da erkek fark etmeksizin bu tür yayınlardan öğrenme olanağına sahiptir.

\section{Ev İdaresi Derslerinin Müfredattaki Yeri ve İçeriği}

Osmanlı mekteplerinde okutulan derslerin haftada kaç saat ve hangi içerikte okutulacağı müfredat programları, talimatnameler ve nizamnameler ile düzenlenmektedir. Ev idaresi ile ilgili derslerin nasıl okutulacağı da bu minvalde çeşitli kaynaklarda açıklanmaktadır. 1910 tarihli Amelî Fenn-i Tedris kitabında Sabri Cemil, biçki ve dikişin bir ev kadınının tek uğraşı olmadığını dolayısıyla mektepte kızların sadece bu dersleri öğrenmesinin yeterli olmadığını savunmakta, idâre-i beytiye dersinin pratiğe dönük içeriğiyle bu dersleri tamamlaması gerektiğini ifade etmektedir. Sabri Cemil, bu derslerin ilköğretim tahsilinin bir kısmını teşkil etmesi gerektiğini “Amele kızını kabul eden mekteb-i ibtidai yemek pişirmek sanatını talim edecek bir seviye-i ameliyeye niçin inmesin?" sözleriyle savunmaktadır. ${ }^{64}$ Hemen akabinde ise Belçika mekteplerinin on bir maddelik idâre-i beytiye programının içeriğini açıklamaktadır:

1. Bir meskenin şerâit-i sıhhiyesi, tecdid-i hava ve nezafet, 2. Eşya-yı beytiye ve hüsn-i muhafazası, 3. Usûl-i teshin ve tenvir, 4. Çamaşır yıkama, sabunlama, klor mâyiâtı istimali, leke çıkarma, 5. Çamaşır, yatak takımı ve elbisenin hüsn-i muhafazası, 6. Tegaddiye ait nesâyih-i ameliye: ağdiyenin evsafi, muhafazası, 7. Aşçılığa dair malumat-1 umûmiye, 8. Meşrubat, 9. Matbah edevatı, 10. Gençlerin tuvaleti, 11. Aile vâridât ve mesârifi. ${ }^{65}$

62 Ahmed Edib, İktisâd-ı Beytî, 40.

63 "İfade-i Mahsusa", Affiyet, 1, 26 Teşrînievvel 1329/8 Kasım 1913, s. 2. Affiyet, "Siyasetden maada, mesâil-i sıhhiye, beytiye ve idâriyeden bahs eden resimli gazetedir" başlığıyla 26 Teşrînievvel 1329 ile 24 Kânûnisânî 1330 (8 Kasım 1913-6 Şubat 1915) tarihleri arasında 15 ay boyunca 64 sayı olarak yayımlanmıştır. Bkz. Cem Hakan Başaran, "Osmanlı Son Döneminde İlginç Bir Tıbbi Süreli Yayın: Âfiyet Gazetesi (Afiéte La Santé) ve Dizini”, Kebikeç 44 (2017), 113-144.

64 Sabri Cemil, Ameli Fenn-i Tedris, 106.

65 Sabri Cemil, Amelî Fenn-i Tedris, 106-107. 
Ev idaresi derslerinin haftalık ders saati ve içeriği okutulduğu kademeye göre değişmektedir. Bunun yanı sıra hem dersin konuları hem de haftalık ders saati yıllar içerisinde yayımlanan yeni düzenlemeler ile değişmiş gözükmektedir. 1316/1898-1899 tarihli Maârif Salnâmesi'nde yayımlanan, ibtidaiye kısmını da içeren altı yıllık kız rüşdiyesi programında ilk üç yıl müfredat programında idâre-i beytiye dersi bulunmazken, sonraki üç yıl idâre-i beytiye dersi haftada iki saat olarak programda yer almaktadır. ${ }^{66}$ Derste ele alınacak konular ise altı kısma ayrılmış ve yılda iki kısmın okutulması öngörülmüştür. Buna göre mekâtib-i rüşdiyenin dördüncü senesinde mesken ve elbise, beşinci senesinde gıdaların muhafazası ve ev eczanesi ve altıncı senesinde haneye ait tabâbet (hekimlik) ve hıfz-1 sıhha ile ev hanımının vezâif-i ahlakiyesi başlıkları altında konular ele alınmaktadır. ${ }^{67}$

Tablo 1: İbtidaiye ve rüşdiyeden oluşan ve eğitim süresi altı yıl olan kız rüşdiyelerine mahsus ders program1. ${ }^{68}$

Sınıf-1 İbtidaiye ve Rüşdiyeden Mürekkeb ve Müddet-i Tahsiliyeleri Altı Seneden İbaret Olan İnas Rüşdiyelerine Mahsus Ders Programı

\begin{tabular}{|l|c|c|c|c|c|c|}
\hline \multicolumn{7}{|c|}{ Mevâd-1 Tedrisiyenin Senelere Taksimi } \\
\cline { 2 - 7 } & $\begin{array}{c}\text { Birinci } \\
\text { Sene }\end{array}$ & İkinci Sene & $\begin{array}{c}\text { Üçüncü-1 Tedrisiye } \\
\text { Sene }\end{array}$ & $\begin{array}{c}\text { Dördüncü } \\
\text { Sene }\end{array}$ & $\begin{array}{c}\text { Beşinci } \\
\text { Sene }\end{array}$ & $\begin{array}{c}\text { Altınc1 } \\
\text { Sene }\end{array}$ \\
\hline Elifba ve Şifahi Malumat & 18 & - & - & - & - & - \\
\hline Kuran-1 Kerim mea Tecvid & 4 & 6 & 5 & 3 & 2 & 1 \\
\hline Ulûm-1 Diniye & - & 2 & 2 & 2 & 2 & 2 \\
\hline Kıraat & 4 & 4 & 4 & 2 & 1 & 1 \\
\hline İmla & 4 & 4 & 3 & 2 & 1 & 1 \\
\hline Kitabet & - & - & - & - & 1 & 1 \\
\hline Kavaid-i Lisan-1 Osmani & - & - & 2 & 2 & 1 & 2 \\
\hline Arabi & - & - & - & - & 2 & 2 \\
\hline Farisi & - & - & - & - & 1 & 1 \\
\hline Hüsn-i Hat & - & 2 & 2 & 1 & 1 & 1 \\
\hline Dürûs-1 Eşya ve Malumat-1 Nafia & 2 & 2 & 2 & 1 & 1 & 1 \\
\hline İdâre-i Beytiye & - & - & - & 2 & 2 & 2 \\
\hline Ahlak & - & - & - & 1 & 1 & 2 \\
\hline Hıf-1 Sıhha & - & - & - & - & 1 & 1 \\
\hline Hesab & 2 & 2 & 2 & 2 & 1 & 1 \\
\hline Coğrafya & - & - & - & 2 & 2 & 2 \\
\hline Tarih & - & - & - & 2 & 2 & 1 \\
\hline El Hünerleri & 2 & 2 & 2 & 2 & 2 & 2 \\
\hline & 18 & 24 & 24 & 24 & 24 & 24 \\
\hline
\end{tabular}

Ev idaresine yönelik yazılmış ders kitaplarında konu dağılımı müfredat programları ve talimatnamelerde öngörülen içeriğe uygun olmakla birlikte ele alınacak konulardan

66 Salnâme-i Nezaret-i Maârif-i Umûmiye (İstanbul: Matbaa-i Amire, 1316/1898-1899), 393.

67 Salnâme (1316/1898-1899), 418-422.

68 Salnâme (1316/1898-1899), 393. 
bir kısmının seçilmesi, bazılarına görece olarak daha fazla ağırlık verilmesi yazarların inisiyatifinde gözükmektedir. Nitekim inâs ibtidaiye ve rüşdiyelerinin farklı kademeleri için farklı yazarlar tarafından ders kitapları kaleme alındığı görülmektedir. Çok sayıda idâre-i beytiye ders kitabı yazan isimlerden biri olan Ali Rıza'nın inâs mekteplerinin dördüncü ve beşinci senelerinde okutulmak üzere çok sayıda baskısı yapılan iki ders kitabı mevcuttur. Erkek ve kız ibtidaiye, rüşdiye ve idadiye mekteplerinin programlarında okutulacak ders kitaplarının yer aldığı 1326/1910-1911 tarihli ders kitapları cetvelinde Ali Rıza'nın bu iki kitabı da zikredilmektedir. ${ }^{69}$ Ali Rıza, 1315/1899-1900 tarihli, dördüncü sınıf için hazırladığı kitapta konu başlıklarını mesken seçimi, şerâit-i sıhhıye, hanenin iç taksimatı, havalandırılması, oturulan mahallerde sıcaklık derecesi, esas-1 beytiye, ev eşyasının yerleştirilmesi, odaların hüsn-i muhafazası, esas-1 beytiyenin hüsn-i muhafazası, döşeme ve mermerlerin temizlenmesi, gümüş eşya ve mutfak takımlarının temizlenmesi, odun ile ısınma, maden kömürü ve kok, odun kömürü, bir ocağın şartları, aydınlatma usûlleri olarak belirlemiştir. ${ }^{70}$ Beşinci sınıf için olan kitabını ise tamamen gıda ve yemek ile ilgili konulara ayırmış, ekmek, et, balık, yumurta, kahve, çay, çikolata gibi başlıklar altında bu gıdaların hazırlanması ve saklanması konusunda bilgiler vermiştir. Gıda ile ilgili başlıklara ilaveten dönemin usûlüne ve muâşeretine uygun olarak hem alaturka hem de alafranga sofra hazırlama usûlleri üzerine bilgiler de vermektedir. ${ }^{71}$

1332/1916-1917 y1lında yayımlanan Mekâtib-i İbtidaiye Altı Dershane ve Muallimli Inas Mekteplerine Mahsus Tevzi-i Ders Cedveli'nde ise idâre-i beytiye ilk dört yıl haftada iki saat ve sonraki iki yıl ise haftada bir saat olarak okutulmaktadır. Dersin içeriğinin açıklandı̆̆ı bölümde ise dersin adı iktisâd-1 beytî olarak ifade edilmekte ve bu dersin devre-i âliye birinci ve ikinci sınıflarında okutulması gereken konular açıklanmaktadır. Buna göre birinci sınıfta iktisâd-1 beytînin tanımı, önemi ve faydası ile kadınların ilim tahsil etmesinin gerekliliği gibi giriş konularından sonra mesken, hıfz-1 sıhha, diş ve saç bakımı, temizlik, zaman tanzimi, yangın ve sigortalar gibi temel konular, ikinci sınıfta ise mobilyalar, hane muhasebesi, hasta bakıcılı̆̆ ev eczanesi, âdâb-1 muâşeret, nezaket, giyinme, sofra âdâbı, ziyaret ve konferanslar gibi daha incelikli konular ele alınmaktadır. ${ }^{72}$ Ayrıca aynı programda bir de aşçılık dersi yer almaktadır. Tabâhat-1 Nazarî (teorik aşçılık) son iki yılda haftada bir saat ve Tabâhat-i Amelî (uygulamalı aşçılık) ise son iki yılda haftada üç saat olarak okutulmaktadır. ${ }^{73}$ 1316/1898-1899 tarihli salnâmede yayımlanan altı yıllık kız ibtidaiye ve rüşdiyesi programı, 1332/1916-1917 tarihli rüşdiye ile birlikte altı yıl olan ibtidaiye programıyla karşılaştırıldığında idâre-i beytiye dersinin haftalık ders saatinin arttığı ve aşçılığın ayrı bir ders olarak müfredata eklendiği görülmektedir.

69 Zekûr ve İnâs İbtidaiye ve Rüşdiye ile Mekâtib-i İdadiye Dâhilinde Bulunan Rüşdiye Stnıflarına ve Bilumum Mekâtib-i İdadiyeye Mahsus Ders Kitaplarl Cedvelidir (1326/1910-1911), 2.

70 Ali Rıza, İâre-i Beytiye (Birinci Kitap) (1315/1899-1900).

71 Ali Riza, Ídare-i Beytiye (İkinci Kitap) (1315/1909-1910).

72 Mekâtib-i İbtidaiye Ders Müfredatı, 138-139.

73 Mekâtib-i İbtidaiye Ders Müfredatı, 25. 
Tablo 2: Altı derslikli ve öğretmenli kız mekteplerine mahsus ders cetveli. ${ }^{74}$

\begin{tabular}{|c|c|c|c|c|c|c|}
\hline \multicolumn{7}{|c|}{ Alt1 Dershane ve Muallimli İnas Mekteplerine Mahsus Tevzi-i Ders Cetveli } \\
\hline \multirow[t]{2}{*}{ Dersler } & \multicolumn{2}{|c|}{ Devre-i Ûlâ } & \multicolumn{2}{|c|}{ Devre-i Mutavassita } & \multicolumn{2}{|c|}{ Devre-i Âliye } \\
\hline & $\begin{array}{l}\text { Birinci } \\
\text { Sene }\end{array}$ & $\begin{array}{l}\text { İkinci } \\
\text { Sene }\end{array}$ & $\begin{array}{l}\text { Üçüncü } \\
\text { Sene }\end{array}$ & $\begin{array}{l}\text { Dördüncü } \\
\text { Sene }\end{array}$ & $\begin{array}{l}\text { Beşinci } \\
\text { Sene }\end{array}$ & $\begin{array}{c}\text { Altınc1 } \\
\text { Sene }\end{array}$ \\
\hline Elifba ve Ecza-i Şerife & 6 & - & - & - & - & - \\
\hline Kuran-1 Kerim ve Malumat-1 Diniye & 1 & 4 & 4 & 4 & 3 & 3 \\
\hline $\begin{array}{l}\text { Musahabat-1 Ahlakiye (Tarihiye, } \\
\text { Sihhiye ve Medeniye) }\end{array}$ & 3 & 2 & 2 & 1 & 1 & 1 \\
\hline Kiraat & 3 & 3 & 2 & 2 & 2 & 2 \\
\hline İmla & - & 1 & 1 & 1 & 1 & 1 \\
\hline Ezber (İnşad ve Tarihi Temsiller) & 1 & 1 & 1 & 1 & 1 & 1 \\
\hline Yazı (Sülüs ve Rika) & - & - & 1 & 1 & 1 & 1 \\
\hline Sarf ve Nahiv & - & 2 & 2 & 1 & 1 & 1 \\
\hline Tahrir & - & 1 & 1 & 2 & 2 & 2 \\
\hline Tarih & - & 2 & 2 & 2 & 2 & 2 \\
\hline Coğrafya & - & 1 & 1 & 2 & 2 & 2 \\
\hline Hesap & 4 & 3 & 2 & 2 & 2 & 2 \\
\hline Hendese & - & - & 1 & 1 & 1 & 1 \\
\hline Eşya Dersleri & 4 & 2 & 2 & 2 & 2 & 2 \\
\hline İdâre-i Beytiye & 2 & 2 & 2 & 2 & 1 & 1 \\
\hline El İşleri & 2 & 2 & 2 & 2 & 2 & 2 \\
\hline Resim & 1 & 1 & 1 & 1 & 2 & 2 \\
\hline Musiki (Gina) & 1 & 1 & 1 & 1 & 1 & 1 \\
\hline Terbiye-i Bedeniye, Sihhiye, Oyun & 2 & 2 & 2 & 2 & 2 & 2 \\
\hline Tabâhat-i Nazarî & - & - & - & - & 1 & 1 \\
\hline Tabâhat-i Amelî & - & - & - & - & 3 & 3 \\
\hline Yekûn & 30 & 30 & 30 & 30 & 33 & 33 \\
\hline
\end{tabular}

İbtidaiye programında olduğu üzere dârülmuallimât programında da ev idaresi derslerinin haftalık ders saati ve içeriği zaman içerisinde değişmiş gözükmektedir. 1869 tarihli Maârif-i Umûmiye Nizamnâmesi'nde dârülmuallimâtın sıbyan bölümünde dikiş ve nakış, rüşdiye bölümünde ise tedbîr-i menzil dersi yer almaktadır. ${ }^{75} 1895$ yılında yayımlanan Dârülmuallimât ile Ihtiyat Kısmına Mahsus Talimatname'de üç yıllık programda idâre-i beytiye dersi yer almakta ve bu ders ilk yıl hafta bir, sonraki yıllar haftada iki saat olarak okutulmaktadir. ${ }^{76}$ $\mathrm{Bu}$ dersin içeriğine dair açıklama bölümünde ise rüşdiyede okutulan konuların daha tafsilatlı okutulacağ 1 , ilaveten çocuk terbiyesi ve yemek konularına yer verileceği zikredilmektedir. ${ }^{77}$

74 Mekâtib-i İbtidaiye Ders Müfredatı, 25

751869 tarihli Maârif-i Umûmiye Nizamnâmesi, 69. ve 70. Maddeler için bkz. Mahmud Cevad, Maârif-i Umûmiye Nezareti, 485.

76 Dârülmuallimât ile Ihtiyat Kısmına Mahsus Talimatname. Bkz. Salnâme-i Nezaret-i Maârif-i Umûmiye (1318/1900-1901), 311. 1316 tarihli salnâmede de aynı ders programı yer almakta fakat talimatnameye yer verilmemektedir. Bkz. Salnâme (1316/1898-1899), 453.

77 Salnâme (1318/1900-1901), 358. 
Tablo 3: 1895 tarihli dârülmuallimât programı. ${ }^{78}$

Dârülmuallimât Programı (1895)

Mevâd-1 Tedrisiye'nin Senelere Taksimi

\begin{tabular}{|l|c|c|c|}
\hline & Birinci Sene & İkinci Sene & Üçüncü Sene \\
\hline Tecvid ve Kuran-1 Kerimde Tatbikatı & 2 & 1 & 1 \\
\hline Ulûm-1 Diniye & 2 & 2 & 2 \\
\hline Arabi & 2 & 2 & 1 \\
\hline Farisi & 1 & 1 & 1 \\
\hline Kavaid-i Osmaniye ve Müntehabâtı & 1 & 1 & 2 \\
\hline Kitabet ve Tatbikat-1 Kavaid & 1 & 1 & 1 \\
\hline Hüsn-i Hat & 1 & 1 & 1 \\
\hline Usûl-i Tedris & 2 & 1 & 1 \\
\hline Ahlak & - & 2 & 1 \\
\hline İlm-i Eşya & 1 & 1 & 1 \\
\hline Mevâlid ve Ulûm-1 Tabiiye & - & 1 & 1 \\
\hline Hifz-1 Sihha & - & 1 & 2 \\
\hline İdâre-i Beytiye & 1 & 2 & 1 \\
\hline Hesab & 2 & 1 & 1 \\
\hline Hendese & 1 & 1 & 1 \\
\hline Resim & 1 & 1 & 1 \\
\hline Coğrafya & 2 & 1 & 1 \\
\hline Tarih & 1 & 1 & \\
\hline Musiki & 1 & 26 & \\
\hline El Hünerleri & 26 & 1 & 1 \\
\hline & 1 & 1 & 1 \\
\hline
\end{tabular}

1330/1914-1915 tarihli Dârülmuallimât Programı'nda ise idâre-i beytiye dersinin alt konulara bölünerek ayrı birer ders olarak okutulduğu görülmektedir. Buna göre idâre-i beytiye dersi ile birlikte dikiş ve tamir, tabâhat, çamaşır yıkama, ütü ve tathir dersleri yer almakta ve dikiş ve tamir dersi her yıl olmak üzere diğerleri dört yıllık programın son iki senesinde okutulmaktadır. ${ }^{79}$ Buna göre programda iktisâd ve idâre-i beytiye olarak adı geçen geçen ders, üçüncü senede idâre-i beytiye, dördüncü senede ise idâre ve iktisâd olarak okutulmaktadır. Üçüncü senenin konuları idâre-i beytiye fenni, amacı ve önemi, ev kadınına lazım olan malumat, hanede intizam, mesken, melbûsât ve gıdalar olarak belirlenirken, dördüncü senede idare ve iktisâdın mahiyeti ve gayesi, defter tutma usûlü, alışverişte iktisâda riayet, orta halli bir ailenin bütçesi, iktisâd sandıkları, sigorta sandıkları, ilk iktisâd sandıklarının kadınların teşebbüsüyle ve kadınlar tarafından teşkili, kadınların mesaisi, kadınların evde ve hariçte tarz-1 mesaisi, kadınların dâhil olabileceği meslek ve sanatlar, genç kızların dâhil olabileceği meslek ve sanatlar, kadınlara ait mesainin tanzimi gibi geniş çaplı bir konu yelpazesi mevcuttur. ${ }^{80}$ 1331/1915-1916 yılında yayımlanan Dârülmuallimîn ve Dârülmuallimât Nizamnâmesi’nde

78 Salnâme (1318/1900-1901), 311.

79 Maârif-i Umûmiye Nezareti Dârülmuallimât Programı (İstanbul: Matbaa-i Amire, 1330/1914-1915), 4.

80 Dârülmuallimât Programı, 89-92. 
de önceki yıl yayımlanan Dârülmuallimât Programı'nda kısmi değişikliler yapılmış ancak ev idaresi ile ilgili olarak programa el ve iğne işleri eklenmiş, idâre-i beytiye, dikiş, tamir, tabâhat, çamaşır yıkama, ütü, tathir ve pirografi dersleri programda yerini korumuştur. ${ }^{81}$

Tablo 4: İbtidaiye dârülmuallimâtı programı. ${ }^{82}$

\begin{tabular}{|c|c|c|c|c|c|}
\hline \multicolumn{6}{|c|}{ Dârülmuallimât-1 İbtidaiyeye Mahsus Tevzi-i Ders Cedveli } \\
\hline & $\begin{array}{l}\text { Sinıf-1 } \\
\text { İhzari }\end{array}$ & $\begin{array}{c}\text { Birinci } \\
\text { Sene }\end{array}$ & İkinci Sene & $\begin{array}{l}\text { Üçüncü } \\
\text { Sene }\end{array}$ & $\begin{array}{c}\text { Dördüncü } \\
\text { Sene }\end{array}$ \\
\hline Kuran-1 Kerim & 2 & 1 & 1 & 1 & - \\
\hline Ulûm-1 Diniye & 2 & 1 & 1 & 1 & 1 \\
\hline İlm-i Ahval-i Ruh & - & - & 1 & 1 & - \\
\hline Ahlak & - & - & 1 & 1 & - \\
\hline Fenn-i Terbiye ve Tedris ve Mektep İdaresi & - & - & - & 1 & 2 \\
\hline \multirow{5}{*}{$\begin{array}{l}\text { Türkçe Kıraat ve İnşad } \\
\text { İmla } \\
\text { Sarf ve Nahiv } \\
\text { Edebiyat } \\
\text { Kitabet }\end{array}$} & 3 & 3 & 2 & 1 & 1 \\
\hline & 3 & 2 & 1 & - & - \\
\hline & 1 & 2 & 1 & - & - \\
\hline & - & - & - & 2 & 1 \\
\hline & 1 & 1 & 1 & 1 & 1 \\
\hline Coğrafya & 1 & 2 & 2 & 1 & - \\
\hline Kozmografya & - & - & - & - & 1 \\
\hline Tarih & 1 & 2 & 2 & 1 & 1 \\
\hline Malumat-1 Medeniye ve Hukukiye & - & - & 1 & - & - \\
\hline Lisan & 2 & 2 & 2 & 2 & - \\
\hline Usûl-i Defteri & - & - & 1 & - & - \\
\hline Hesab & 4 & 3 & 2 & 2 & 1 \\
\hline Hendese & - & 2 & 2 & 1 & - \\
\hline Cebir & - & - & - & 1 & 1 \\
\hline Malumat-1 Tabiye & - & 2 & 2 & 2 & 1 \\
\hline Hat & 2 & - & - & - & - \\
\hline Resim & 3 & 3 & 2 & 1 & 1 \\
\hline Pirografi & - & - & - & 1 & - \\
\hline Musiki ve Gına & 2 & 2 & 2 & 2 & 2 \\
\hline Terbiye-i Bedeniye & 2 & 2 & 2 & 1 & 1 \\
\hline Hıfz-1 Sihha ve Takayyüdât-1 Sihhiye & - & - & 1 & 1 & - \\
\hline Dikiş ve Tamir & 4 & 3 & 3 & 2 & 2 \\
\hline Tabâhat & - & - & - & 2 & 2 \\
\hline İktisâd ve İdâre-i Beytiye & - & - & - & 1 & 1 \\
\hline Sanayi-i Ziraiye ve Bahçıvanlık & - & - & - & 1 & 2 \\
\hline Çamaşır Yıkama ve Ütü ve Tathir & - & - & - & 2 & 2 \\
\hline Tatbikat-1 Dersiye & - & - & - & - & 9 \\
\hline Yekûn & 33 & 33 & 33 & 33 & 33 \\
\hline
\end{tabular}

1895 yılında yayımlanan üç yıllık Dârülmuallimât Programı ile 1330/1914-1915 ve

81 Mâ̂rif-i Umûmiye Nezareti Dârülmuallimîn ve Dârülmuallimât Nizamnamesi (İstanbul: Matbaa-i Amire, 1331/1915-1916), 9.

82 Dârülmuallimât Programı, 4. 
1331/1915-1916 yıllarında yayımlanan dârülmuallimât programları karşılaştırıldığında müfredatta ders çeşitliliğinin arttığı ve idâre-i beytiye dersinin tematik olarak alt derslere bölünerek çeşitlendiği ve ev idaresi ile ilgili derslerin ders saatinin ve ağırlığının arttığı görülmektedir. Sonuç olarak gerek altı yıllık ibtidaiye ve rüşdiye programlarında ve gerekse dârülmuallimât programlarında, 1316/1898-1899 ve 1318/1900-1901 tarihli salnâmelerde yayımlanan programlar esas alındığında 1914 ve sonrasında kız mekteplerinin tüm kademelerinde derslerin genel olarak çeşitlendiği ve kız mekteplerine özgü olan idâre-i beytiye dersinin haftalık ders saatinin arttığı ve bu derse ilaveten müfredata ev idaresi ile ilgili, dikiş, aşçılık, çamaşır, ütü ve pirografi gibi yeni dersler ilave edildiği görülmektedir. Kadınlığa müteallik dersler olarak telakki edilen bu derslerin müfredat programında sayıca artması ve çeşitlenmesi, kızların eğitiminde ev kadınlığı vurgusunun güçlendiği izlenimini vermektedir.

\section{Kız Mekteplerinin Müfredatına Dair Tartışmalar}

Kız çocuklarının eğitimi, kız mekteplerinin müfredat programlarının içeriği, ev idaresine yönelik derslerin müfredattaki yeri ve nasıl okutulması gerektiği ders programlarını düzenleyen ve hazırlayan Osmanlı bürokratlarının ve siyasi otoritelerinin olduğu kadar dönemin entelektüellerinin, eğitim çevrelerinin ve Osmanlı kadınlarının da gündemindedir. Hanımlara Mahsus Gazete'nin 10 Kasım 1895 tarihli sayısında kadınların eğitiminin nasıl olması gerektiğine dair kapsamlı bir makale yayımlanmıştır. Dört sayı boyunca yayımlanan bir yazı dizisinin bir bölümü olan ve yazar ismi verilmeksizin yayımlanan bu makale, ev idaresi derslerinin kadının eğitimindeki yerini ve önemini tartışmakta, bu derslerin yeterince verilmemesi durumunda ortaya çıkan sonuçları Avrupa ve Amerika'dan örnekler vererek göstermeye çalışmaktadır. Makale dönemin kadınlara yönelik eğitim politikalarını değerlendirmekte ve kız mekteplerinin müfredat programlarını düzenleyen mecralara yön gösterme çabası taşımaktadır. Makalede, öncelikle kadınların âlem-i medeniyette pek çok alanda erkekler ile aynı eğitimi alma noktasına eriştiği ve erkekler ile ilim ve fende yarışır duruma geldiği ancak bu eğitimin istenilen sonuçları verip vermediği tartışılmaktadır. Makale, âlem-i medeniyette kadınların kadınlığı unuttuğuna dair şikâyetlerin her geçen gün arttığını, kadınlardan önce evlatlarına muhabbet göstermeleri ve ailelerine saadet temin etmeleri beklenirken kadınlarda bunu temin eden hislerin azaldığını iddia etmektedir. Makaleye göre medeni milletlerde kadınlar, idâre-i beytiye, çocukların terbiyesi, zevcinin ve çocuklarının istirahatini temin ve istihsal ile uğraşmaktan hoşlanmamak tavrını göstermektedirler. Yazının ulaştığı sonuç ise "Usûl-i terbiye-i medeni, medeni nisvanı saadet-i aileyi ve saadet-i umûmiye-i milliyeyi istihsale say" edecek surette yetiştirmemektedir". ${ }^{83}$ Bunun sebebi ise zihinsel yetenekleri ve fitratları farklı olan kadınların erkekler ile aynı eğitimi

83 “Kızların Tahsili Hakkında Bir Mütalaa 2”, Hanımlara Mahsus Gazete 21 (30 Teşrînievvel 1311/10 Kasım 1895), 1-2. 
almalarıdır. Makaleye göre eğer kadınlar yaratılıştan gelen fitri yeteneklerinden istifade etmeyip erkek terbiyesine yani erkeklerin ömür geçirdikleri geniş dairede gezebilmek için lazım gelen malumata yönelirse, bu alanda erkekler kadar kabiliyet gösterememekle birlikte asıl kabiliyetlerinin görüleceği nazik hizmetlerde yüzüstü kalmaktadırlar. Bu durumda, makaleye göre kadınların insanlığın saadeti için fitratlarının müsait ve meyyal olduğu tahsil ile uğraşmaları ve kadınlara mahsus vazifelerini yerine getirmeye yardım edecek ilim ve fen tahsil etmeleri en uygun ve en çok üzerinde mutabık olunan yoldur.

Avrupa'nın en büyük inâs mekteplerinde ikmal-i tahsil eden kılar cebirde, hendesede fevkalade irfan gösterip mesâil-i mühimme-i riyaziye-yi hale iktidar kesb etmeleri, ilm-i heyette bu kızların malumat-1 tekmil-i seyyarat ve kevakibin hareketini bilmek ve şems ve kamerin bünye ve terkibini tayin eylemek, hikmet ve kimyada tecârüb-i mühimme-i fenniye icra etmek derecesinde iktidar-1 ilmî göstermeleri herkesin nazar-1 takdirini celb ediyor. [...] Fakat ailelerinin saadet halini yani saadet-i umûmiye-i milliyeyi temine bunlar kâfi gelir mi? Bu kızlar ulûm-1 âliyede maharet ve irfanlarına bedel bir aile teşkil ettikleri zaman aile umûrunda bigâne bulunuyorlar. Çamaşır yıkayamadıkları gibi yıkayanlara nezaret hususunda istidat göstermiyorlar. Yemek pişirenlerin kusurunu tashihe gayrimuktedir bulunuyorlar. Hülasa, idâre-i beytiyede o kadar ulûm ve fünûn-1 mütenevvia kendilerini ikdâr edemiyor. Bunun neticesi olarak ailelerde böyle mükemmel tahsil gören kızlar zevcinin ve evladının istirahatini temin edecek surette hareket edemiyorlar. ${ }^{84}$

Makalenin sonunda Osmanlı'da da bu durumun yaşanmaması için mevcut müfredat programlarında değişikliğe gidilmesi önerilmektedir. Değişikliğin mahiyeti konusunda ise yine Avrupa ve Amerika'dan örnek verilmektedir. Yazıda ifade edildiğine göre Almanya, Amerika ve Belçika'da kız mekteplerinin müfredat programında yakın zamanda sslahat ve tadilat yapılmıştır, Buna göre beş kıtanın ayrıntılı coğrafyası, ecza-yı kimyevinin ayrıntılı konuları, burçların suret-i teşkili, seyyarelerin hareketleri müfredattan çıkarılmıştır. Bunun yerine haftada bir gün mektebe çamaşır gönderip kız çocuklarına çamaşır yıkama yolları gösterilmekte, bir gün mutfakta bütün teferruatıyla aşçılık sanatı öğretilmekte, ertesi gün yukarıdan aşağıya mektep sildirilip süpürttürülmekte, başka bir günde mektebe yakın bir kadın hastanesinde hasta baktırılmakta ve bir gün de küçük çocukların bulunduğu bir hanede çocuklara nezaret ettirilmektedirler. Hanımlara Mahsus Gazete' de isimsiz olarak yayımlanan bu yazı dizisi bir anlamda derginin kadınların eğitiminin mahiyeti ve çerçevesi konusunda genel görüşünü yansıtmaktadır. ${ }^{85}$

Kız mekteplerinin müfredat programlarında yeniliklerin gündeme geldiği bu dönemde makalenin yayımlanmış olması önemlidir. Nitekim 1895 yılına kadar kız mekteplerinin müfredatının tam teşekküllü olarak hazırlanmadığı ve kız mekteplerine özgü derslerin müfredatta yer almakla birlikte bu derslerde okutulmak üzere müfredata uygun ders

84 "Kızların Tahsili Hakkında", 2.

85 "Osmanlı kadın dergilerinde kızların eğitimi konusunda kaleme alınan yazılar ile ilgili olarak daha fazla örnek için bkz. Savaş Karagöz ve Mustafa Şanal, "II. Meşrutiyet Dönemi Kadın Gözüyle Kadın Eğitimi”, The Journal of International Social Research 8/39 (2015), 679-691. 
kitaplarının yeterli olmadığı görülmektedir. Ev idaresi ile ilgili okutulan kademeye göre ders kitabı yazımı 1899 sonrasında Ali Rıza'nın yazmış olduğu idâre-i beytiye ders kitaplarıyla başlamakta ve sonrasında çok sayıda idâre-i beytiye ve iktisâd-ı beytî ders kitabı yayımlanmaktadır. Bu ders kitaplarının genellikle giriş bölümlerinde Hanımlara Mahsus Gazete' de tartışıldığ 1 şekliyle kadınların eğitimi ve kız mekteplerinin müfredat programında ev idaresi derslerinin gerekliliği vurgulanmaktadır. Çok sayıda ders kitabının ve bilhassa idâre-i beytiye ders kitabının yazarı olan Nazım, aradan yirmi yıldan fazla bir zaman geçtikten sonra, 1334/1918-1919 tarihli İdare-i Beytiye ders kitabında kadınların ev idaresi öğrenmesinin neden gerekli olduğunu Hanımlara Mahsus Gazete' de ortaya konan söylem ve gerekçeler çerçevesinde izah etmektedir.

Okuyup yazma bilmek bir kız için âlâdır. Bir karyola düzeltmesini, pencere camlarını silmesini bilmek ise elzemdir. Coğrafya fâideli bir ilimdir, fakat kıt'at-1 hamseyi bilmekle aile fertlerinin karnı doymaz. Akşamüzeri aç ve yorgun olarak hanesine avdet eden bir peder aile reisesinin tarihe olan vukufundan bir şey anlamaz. Güzelce pişmiş üç kap yemeğe ihtiyaç gösterir. Bunun için sizin mektepte muhtelif ilimlerle beraber idâre-i beytiye dersini de öğrenmeniz ve öğrendiğiniz şeyleri tatbike çalışmanız iktiza eder. ${ }^{86}$

İdâre-i beytiye dersinin müfredattaki ağırlığını yetersiz bulan kadınlar Fransızca, Arapça ve Farsça gibi dil derslerini gereksiz görmekte, felsefe ve kimya gibi derslerin kızların ilgisine mazhar olmakla birlikte ev idaresi ve aile saadetine katkı sağlamadığını düşünmekte ve bu derslerin yerine idâre-i beytiye, biçki, dikiş ve hıfz-1 sıhha gibi derslerin müfredatta ağırlığının artmasını istemektedirler. Sıdıka Ali Rıza, Kadınlar Dünyası'nda "Mekteplerimiz” başlıklı yazısında kız öğrencilerin rüşdiye mekteplerinde kendilerine lazım olan sanat-1 terbiye, umûr-1 beytiye, kavâid-i sıhhiye, vezâif-i zevciye, biçim ve dikişte yeterli malumatı alamadıklarını savunmaktadır. Sıdıka Ali Rıza, inâs rüşdiye müfredatının yeniden gözden geçirilmesini ve kız öğrencilerin eğitim süresinin genellikle erkeklerden daha kısa olması dolayısıyla bu kısa zaman zarfında kız çocuklarının ihtiyacına cevap verecek nitelikte derslerin okutulmasını, programın Arabi ve Farisi gibi dil derslerinin ağırlığından kurtarılmasını önermektedir. ${ }^{87}$

Öte yandan Şükûfezâr dergisinin sahibi ve yazarı Arife Hanım konuya farklı bir perspektiften yaklaşmaktadır. ${ }^{88}$ Arife Hanım, dârülmuallimâtın ilk mezunlarındandır ve kendisi gibi dârülmuallimâttan mezun bir grup kadınla kadınlar tarafından yayımlanan ilk dergi olma özelliğine sahip Şükûfezâr'ı yayımlamaktadır. Arife Hanım, dergide doğrudan kadın erkek eşitliği tartışmasına girmemekte ancak insanlığa hizmet konusunda kadın ve erkeğin farkı olmadığını savunmaktadır. Ona göre kadınların insanlığa hizmeti sadece çocuk yetiştirmek ve ev işlerini en güzel şekilde yapmak anlamına gelmemektedir. Arife Hanım'a göre insanlığa hizmet derece derecedir ve en yükseği ilim ve marifet ile olandır. ${ }^{89}$

86 Nazım, İdâre-i Beytiye (İstanbul: Garoyan Matbaası, 1334/1918-1919), 7.

87 Sidıka Ali Rıza, “Mekteplerimiz", Kadınlar Dünyasl 17 (20 Nisan 1329/3 Mayıs 1913), 4.

88 Şükûfezâr hakkında detaylı tartışma için bkz. Tunç Yaşar, "İlk Kadın Dergilerinde 'Kadınlık”, 99-114.

89 Arife, "Mukaddime", Şükûfezar 1, (1301/1883-1884), 4. 
Yine Kadınlar Dünyası dergisinde Nilüfer Mazlum, on dokuzuncu yüzyılda kadını noksanlıkları üzerinden sınırlayan algıyı sorgulamakta ve yirminci yüzyılda bunun değiştiğini ifade etmektedir. Nilüfer Mazlum, "Kadınlar evlat yetiştirmekle, vezâif-i umûr-ı beytiyesini hüsn-i suretle ifa etmekle beşeriyete daha çok yardım etmiş olurlar." şeklinde ifade bulan argümanı tasdik ettiklerini ancak insanların tamamının birden eczacı, avukat, makinist olamayacağını, insanlar içinde pek az kimsenin bu sanatlara liyakat kesp edeceğini ifade ederek kadınların da hepsinin birden zürriyet yetiştirmeyi, umûr-1 beytiyeyi ifa etmeyi bir tarafa bırakarak bu türlü işlere girmesinin mümkün olmadığını ifade etmektedir. ${ }^{90}$ Nilüfer Mazlum, kadınların tamamının aynı amaç doğrultusunda eğitilmesini eleştirmekte, kadınların farklı alanlara dâhil olmasının neslin devamı ve ev idaresi gibi hususlarda Osmanlı toplumsal yaşayışına bir tehdit oluşturmayacağını iddia etmektedir.

\section{Sonuç}

Ev idaresinin kız mekteplerinde bir ders vasıtasıyla öğretilmesi pek çok açıdan ele alınıp tartışılabilecek bir meseledir. Bu makalede ağırlıklı olarak konunun iki yönü üzerinde durulmuştur. Geleneksel ev idaresi anlayışının terkedilerek yerine yeni bir ev idaresi anlayışının getirilmeye çalışılması ilk olarak on dokuzuncu yüzyıl ve akabinde gelen modernleşme ve medenileşme süreci ve sürece uyum sağlama çabalarının sonucu olarak Osmanlı sosyopolitik ve kültürel atmosferinde yaşanan değişim ve dönüşüm süreci ile ilgilidir. Öte yandan ev idaresi derslerinin kı mekteplerinin müfredat programında yer alması ile birlikte ev idaresi ve ev kadınlığ 1 artık üzerinde politika geliştirilen bir kamu meselesine dönüşmüş ve doğrudan devletin ilgi alanına girmiştir. Toplumun çekirdeği olan aile ve onun yaşadığı mekân olarak ev, birçok açıdan çetrefilli ve çok katmanlı gözüken Osmanlı modernleşme ve medenileşme sürecinin aynası mahiyetindedir. Osmanlı hanesi, bir taraftan modern ve medeni yurttaş yetiştirme projesinin ilk ayağı olarak dönüştürülmek istenen fakat diğer taraftan Batılı değerlere karşı ailenin korunması misyonu çerçevesinde geleneksel değerleriyle muhafaza edilmek istenen alandır. Dolayısıyla on dokuzuncu yüzyılın ikinci yarısından itibaren bir yandan geleneksel Osmanlı hanesini modern ve bilimsel standartlara yükseltmek için bir gündem söz konusudur. Öte yandan ise ev idaresi eğitimi üzerinden eğitim ve kamusallık imkânları ve alanı genişleyen Osmanlı kadınının geleneksel kodlarla tanımlanış statüsü ve rolleri muhafaza edilmeye çalışılmaktadır.

Geç dönem Osmanlı'da modern ev idaresi fikri çerçevesinde ortaya çıkan literatür, geleneksel ev hayatını dağınık, düzensiz ve gelişigüzel olmakla eleştirmekte, yerine bilimsel, rasyonel ve pedagojik verilere dayanan ve disiplin, düzen ve hijyenin hâkim olduğu yeni bir ev idaresi modeli önermektedir. Mehmed İzzet'in üç ciltlik ev ansiklopedisi, Afiyet gibi genele hitap eden dergiler ve Osmanlı kadın dergileri, sağlık, hijyen koşulları, ev dekorasyonu, yemek pişirme, ev ekonomisi, çocuk bakımı, mutfak organizasyonu gibi bir

90 Nilüfer Mazlum, “Daima Düşünebildiğim”, Kadınlar Dünyası 114 (18 Teşrînievvel 1329/31 Ekim 1913$), 8$. 
dizi meseleye sayfalarında yer vererek doğru ve verimli ev yönetimi hakkında okuyucularına bilgi vermektedirler. Hem kadınlar hem de erkekler tarafından kaleme alınan bu yayınlar, öncelikli hedef kitleleri kadınlarmış gibi gözükse de kadın erkek geniş bir okuyucu kitlesine ulaşma potansiyeli taşımaktadır.

Öte yandan ev idaresinin örgün eğitim sistemi içerisinde kız mekteplerine özgü bir ders olarak tanımlanması ve bu ders üzerinden yapılan tartışmalar konunun Osmanlı siyasi otoritesinin kadın politikası bağlamında tartışılmasını gerektirmektedir. Kız mekteplerinin müfredat programlarını ve ev idaresine yönelik ders kitaplarını hazırlayanlar, klasik dönem ahlak literatüründe aynı kişide toplanan ev reisliği ve ev idareciliği rollerini ayırarak kadına ev idareciliği sorumluluğunu yüklemektedirler. Öte yandan, evde hâlihazırda var olan iş bölümünü değiştirmeyen bu yeni tanımlama, siyasi iradenin haneye ve hane içinde kadınların gündelik hayatına nüfuz ederek kadının temizlik, çamaşır, bulaşık, ütü, yemek, çocuk bakımı, biçki, dikiş ve nakış gibi evi için yaptığı rutin işleri kalite, standart ve zaman tanzimi çerçevesinde programlamaktadır. Ev idaresi derslerinde okutulmak üzere yazılan idâre-i beytiye ve iktisâd-ı beytî ders kitaplarına ve dersin nasıl okutulması gerektiğini açıklayan talimatname ve nizamnamelere bakıldığında ev idaresi eğitiminin, sadece kadınların bilgi ve becerilerini geliştirmek bağlamında kalmadığı, devletin genel olarak yurttaş yetiştirme ve bu minvalde şekillenen kadın politikasını uygulamada somut bir araç olarak kullanıldığ görülmektedir. Geleneksel iş bölümünde kadın işi olarak kabul gören gündelik ev rutinini bilimsel ve rasyonel bir zeminde yeniden tanımlayan idâre-i beytiye dersleri, teknik ve pedagojik malumatın ötesine geçerek kadınlara toplumun çekirdeği olan ailenin refah ve mutluluğunu temin etme ve geleceğin yurttaşları olan çocuklara ilk terbiye ve eğitimi vererek istenilen minvalde yetiştirme sorumluluğunu da yüklemektedir. ${ }^{91}$

Sonuç olarak kız mekteplerinin açılması ve kız çocuklarının sıbyan mekteplerinden sonra rüşdiye, kız sanayi mektebi ve öğretmen okullarına devam etmesi önemli bir gelişmedir ancak kız çocukları için öngörülen eğitimin içeriği, kadınlara zamanın gereği olan malumatı vermenin yanında onların mevcut statüsünü muhafaza etmeye yönelik gibi gözükmektedir. Kız mekteplerine özgü ev idaresi dersleri, Osmanlı kadınının ev kadınlığı rolünü bilimsel, medeni ve pedagojik ölçütlere riayet ederek yapabilmesi için eğitilmesini amaçlamakta ancak "kadınlığa faydalı ilim ve fen" bağlamında şekillenen kız mekteplerinin müfredat programları, kadınların hâlihazırda var olan ev kadınlığı statüsünü değiştirmemekte aksine pekiştirmektedir. $\mathrm{Bu}$ dersler için yazılan kitaplarda kullanılan dil ve üslup, geleneksel kadın söyleminin birçok açıdan devam ettiğini göstermektedir. Bu kitapların devletin açtı̆̆ k1z mekteplerinin ders kitabı olduğu ve her bir ders kitabının Maârif Nezareti'nin izni ile yayımlandığı göz önünde bulundurulduğunda ortaya konan kadın söyleminin sadece kitabın yazarına ait olmadığı düşünülebilir. Bu bağlamda, idâre-i beytiye dersinin müfredat

91 Mine Demir, “Tanzimat’tan Cumhuriyet'in İlk Yıllarına Türkiye'de Ev Kadınlarının Eğitimi”, Çeşm-i Cihan: Tarih, Kültür ve Sanat Araştırmaları E-Dergisi 4/1 (2017), 110. 
programlarında yer alması öncelikle on dokuzuncu yüzyılın ikinci yarısından itibaren Osmanlı hayatının hemen her alanında yaşanan modernleşme ve medenileşme süreci ve buna yönelik siyasi iradenin ortaya koyduğu reform programları ile ilgilidir. Ev, bu değişim ve dönüşüme hizmet edecek ve katkı sağlayacak şekilde modern standartlarda yeniden organize edilmesi gereken bir alan olarak görülmekte ve evin idarecisi olan kadının da bu minvalde eğitilmesi amaçlanmaktadır.

\section{Kaynaklar}

\section{Osmanlıca Ev İdaresi Literatürü}

Ahmed Edib. İktisâd-ı Beytî. İsanbul: Kanaat Kütüphanesi, 1331/1915-1916.

Ali Rıza. Kızlara Mahsus İdâre-i Beytiye (Birinci Kitap). İstanbul: Karabet Matbaas1, 1315/1899-1900.

Ali Rıza. Kızlara Mahsus İdâre-i Beytiye (İkinci Kitap). İstanbul: Karabet Matbaası, İstanbul, 1315/18991900.

Ali Rıza. Kızlara Mahsus İdâre-i Beytiye. İstanbul: Karabet Matbaası, 1323/1907-1908.

Behram Münir. Muhtasar İdâre-i Beytiye. İstanbul: A. Asaduryan Şirket-i Mürettibiye Matbaası, 1321/19051906.

Hüseyin Hıfzı. Tarz-ı Nevin İdâre-i Beytiye. Dersaadet: Arakis Matbaası, 1330/1914-1915.

Mehmed İzzet ve Nazım. İdâre-i Beytiye. İstanbul: Kanaat Kütüphanesi, 1330/1914-1915.

Mehmed İzzet. Rehber-i Umûr-ı Beytiye. Dersaadet: Feridiye Matbaas1, 1319/1901.

Mehmed Rifat. Tedbîr-i Menzilden Hane Bahsi. İstanbul: Mihran Matbaası, 1303/1885-1886.

Melekzâde Fuad. Vezâif-i Beytiyeden Hanımlara Mahsus Aile Dersleri. Dersaadet: Şirket-i Mürettibiye Matbaas1, 1325/1909-1910.

Nazım. Amelî ve Nazarî İktisâd-ı Beytî. Dersaadet: Kitabhane-i İslam ve Askeri, 1334/1918-1919.

Nazım. İdâre-i Beytiye. Hilal Matbaası, 1335/1919-1920.

Nazım. İdâre-i Beytiye. İstanbul: Garoyan Matbaası, 1334/1918-1919.

\section{Süreli Yayınlar}

Âfiyet

Hanımlara Mahsus Gazete

Kadınlar Dünyası

Şükûfezâr

Takvim-i Vekâyi

Terakkî-i Muhadderât

\section{Müfredat Programları, Nizamnameler ve Eğitimi Düzenleyen Diğer Belgeler}

Ayşe Sıdıka. Usûl-i Talim ve Terbiye. İstanbul: Âlem Matbaası, 1313/1895-1896. 
Dârülmuallimât ile İhtiyat Klsmına Mahsus Talimatname. İstanbul: Matbaa-i Amire, 1313/1895.

Maârif-i Umûmiye Nezareti Dârülmuallimât Programı. İstanbul: Matbaa-i Amire, 1330/1914-1915.

Maârif-i Umûmiye Nezareti Dârülmuallimîn ve Dârülmuallimât Nizamnâmesi. İstanbul: Matbaa-i Amire, 1331/1915-1916.

Mekâtib-i İbtidaiye Ders Müfredatı: Altı, Beş, Dört ve Üç Dershane ve Muallimli Mekteplere Mahsus. İstanbul: Matbaa-i Amire, 1332/1916-1917.

Sabri Cemil. Amelî Fenn-i Tedris: Dürûs-ı Mütenevvianın Suret-i Tedrisi, Etfâlin Inzibat ve Terbiyesi, İdare-i Mekâtib. Kosova Matbaas1, 1326/1910-1911.

Salnâme-i Nezaret-i Maârif-i Umûmiye. İstanbul: Matbaa-i Amire, 1316/1898-1899.

Salnâme-i Nezaret-i Maârif-i Umûmiye. İstanbul: Matbaa-i Amire, 1318/1900-1901.

Tedrisat-ı İbtidaiye Kanun-ı Muvakkati. İstanbul: Matbaa-i Amire, 1329/1913.

Zekûr ve Inâs İbtidaiye ve Rüşdiye ile Mekâtib-i İdadiye Dâhilinde Bulunan Rüşdiye Sınıflarına ve Bilumum Mekâtib-i İdadiyeye Mahsus Ders Kitaplarl Cedvelidir. 1326/1910-1911.

\section{Kitap, Makale ve Tezler}

Abdülaziz Bey. Osmanlı Âdet, Merasim ve Tabirleri. ed. Kazım Arısan, Duygu Arısan Günay. İstanbul: Tarih Vakfi Yurt Yayınları, 1995.

Ahmed Midhat. Avrupa Âdâb-ı Muâşereti Yahud Alafranga. İstanbul: İkdam Matbaası, 1312/1896-1897.

Baran Bayülgen, Nilüfer. Rehber-i Umur-u Beytiye: A Guideline in the Socialization of Female Students at the Turn of the Twentieth Century. Yüksek Lisans tezi, Boğaziçi Üniversitesi, 1998.

Başaran, Cem Hakan. “Osmanlı Son Döneminde İlginç Bir Tıbbi Süreli Yayın: Âfiyet Gazetesi (Afiéte La Santé) ve Dizini”, Kebikeç 44 (2017): 113-144.

Çağrıcı, Mustafa. “Tedbîrü'l-Menzil”, TDV İslam Ansiklopedisi. 40: 260-261. Ankara: TDV Yayınları, 2011.

Demir, Mine. “Tanzimat’tan Cumhuriyet'in İlk Yıllarına Türkiye'de Ev Kadınlarının Eğitimi”, Çeşm- $i$ Cihan: Tarih, Kültür ve Sanat Araştırmaları E-Dergisi 4/1, (2017): 108-120.

Devellioğlu, Ferit. Osmanlıca-Türkçe Ansiklopedik Lûgat. Ankara: Aydın Kitabevi, 1998.

Elias, Norbert. The Civilizing Process: The History of Manners and State Formation and Civilization. çev. Edmund Jephcott. Oxford UK \& Cambridge USA: Blackwell, 1994.

Ergin, Osman. Türk Maarif Tarihi. cilt1-2. İstanbul: Eser Matbaas1, 1977.

Karagöz, Savaş ve Şanal, Mustafa. “II. Meşrutiyet Dönemi Kadın Gözüyle Kadın Eğitimi”, The Journal of International Social Research 8/39 (2015): 679-691.

Kâtip Çelebi. Keşfü'z-Zünûn. Dersaadet: Âlem Matbaası,1310/1892.

Kınalızâde Ali Çelebi. Ahlâk-ı Alâî. haz. Mustafa Koç. İstanbul: Klasik Yayınları, 2007.

Richards, M. Virginia. "The Postmodern Perspective on Home Economics History", Journal of Family and Consumer Sciences, 92/1 (2000): 81-84.

Mahmud Cevad İbnü'1 Şeyh Nafi. Maârif-i Umûmiye Nezareti Tarihçe-i Teşkilat ve Ícraatı. İstanbul: Matbaa-i Amire, 1338/1922-1923.

Navora-Yaşın, Yael. ““'Evde Taylorizm”: Türkiye Cumhuriyeti’nin İlk Yıllarında Evişinin Rasyonelleşmesi (1928-40)", Toplum ve Bilim 84 (Bahar 2000): 51-73. 
Orman, Sabri. "İlm-i Tedbîr-i Menzil: Oikonomia ve İktisat”, Sosyo-Kültürel Değişme Sürecinde Türk Ailesi içinde, 265-310. Ankara: T.C. Başbakanlık Aile Araştırma Kurumu, 1992.

Somel, Selçuk Akşin. “Osmanlı Modernleşme Döneminde Kız Eğitimi”, Kebikeç 10 (2000): 223-238.

Somel, Selçuk Akşin. Osmanlı'da Eğitimin Modernleşmesi (1839-1908): İslamlaşma, Otokrasi ve Disiplin. İstanbul: İletişim Yayınları, 2010.

Şanal, Mustafa. “Osmanlı İmparatorluğu’nda Kız Öğretmen Okulunun (Dârülmuallimât), Kuruluşu, Okutulan Dersler ve Kapatılışı (1870-1924)”, Ankara Üniversitesi Osmanlı Tarihi Araştırma ve Uygulama Merkezi Dergisi 26 (Güz 2009): 221-244.

Tanyeli, Uğur. İstanbul'da Mekan Mahremiyetinin İhlali ve Teşhiri: Gerilimli Bir Tarihçe ve 41 Fotoğraf. İstanbul: Akın Nalça Kitapları, 2012.

Tunç Yaşar, Fatma. "II. Meşrutiyet Döneminde Yurttaşlık, Ahlak ve Medenilik Eğitimi: Malumat-1 Medeniye Ders Kitapları”, Osmanlı Araştırmaları / Journal of Ottoman Studies 52 (2018): 311-342.

Tunç Yaşar, Fatma. “İlk Kadın Dergilerinde 'Kadınlık’: İffetli ve Mektepli”, Harf Harf Kadınlar içinde, ed. Nazife Şişman. 99-114. İstanbul: Klasik Yayınları, 2008.

Tunç Yaşar, Fatma. Alafranga Halleri: Geç Osmanlı'da Âdâb-ı Muâşeret. İstanbul: Küre Yayınları, 2016.

Ürekli, Fatma. "Güzel Sanatlar Eğitiminde Osmanlı Hanımlarına Açılan Bir Pencere: İnas Sanayi-i Nefîse Mektebi”, Tarih ve Toplum 39/231 (Mart 2003): 50-60. 